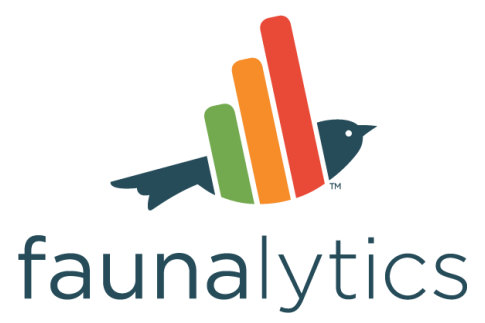

\title{
Beliefs About Fish And Chickens \& Their Relation To Animal-Positive Behaviors
}

November 2020

Authors: Tom Beggs, MA, and Jo Anderson, PhD 


\section{Faunalytics}

\section{Contents}

$\begin{array}{lr}\text { Background } & 4\end{array}$

Key Findings $\quad 4$

$\begin{array}{lr}\text { Recommendations } & 5\end{array}$

$\begin{array}{lr}\text { Research Team } & 6\end{array}$

$\begin{array}{lr}\text { Method Overview } & 7\end{array}$

$\begin{array}{ll}\text { Results } & \mathbf{9}\end{array}$

How Many People Took The Pledge And Signed The Petition? 9

The Most Common Beliefs About Fish \& Chickens $\quad 9$

Which Categories Of Beliefs Were Most Strongly Associated With Animal-Positive Behaviors?

Beliefs About Fish 14

Fish Personality Beliefs $\quad 14$

Fish Emotion Beliefs $\quad 15$

$\begin{array}{ll}\text { Fish Suffering Beliefs } & 17\end{array}$

$\begin{array}{ll}\text { Fish Social Beliefs } & 18\end{array}$

$\begin{array}{ll}\text { Fish Intelligence Beliefs } & 20\end{array}$

Fish Consumption Beliefs $\quad 22$

Other Fish Beliefs $\quad 23$

Beliefs About Chickens $\quad 25$

Chicken Personality Beliefs $\quad 25$

Chicken Emotion Beliefs $\quad 26$

Chicken Suffering Beliefs $\quad 28$

Chicken Social Beliefs $\quad 29$

Chicken Intelligence Beliefs $\quad 31$

Chicken Consumption Beliefs $\quad 34$

Other Chicken Beliefs $\quad 36$

What Role Did Participant Traits Play? 38

$\begin{array}{ll}\text { Conclusions } & \mathbf{4 0}\end{array}$

Which Beliefs Were Most Common? $\quad 40$

Beliefs Most Strongly Associated With Pro-Animal Behavior $\quad 41$

Groups Of Beliefs $\quad 41$ 


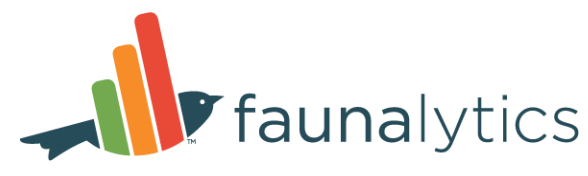

$\begin{array}{ll}\text { Individual Beliefs } & 41\end{array}$

Additional Beliefs Of Interest For Diet Pledges $\quad 42$

Additional Beliefs Of Interest For Petition Signatures $\quad 43$

$\begin{array}{ll}\text { Participant Characteristics } & 43\end{array}$

Interpretation And Future Directions $\quad 44$

$\begin{array}{ll}\text { Supplementary Materials } & 46\end{array}$

Method: Additional Details $\quad 46$

Participants And Power $\quad 46$

$\begin{array}{ll}\text { Correlational Analyses } & 46\end{array}$

$\begin{array}{ll}\text { Petition Measure } & 47\end{array}$

Average Correlation By Group Of Beliefs $\quad 47$

$\begin{array}{ll}\text { Individual Beliefs } & 48\end{array}$ 


\section{faunalytics}

\section{Background}

Animals used for food generally receive significantly less attention and funding than companion animals (Faunalytics, 2019). Small-bodied animals like chickens and fish are killed in particularly massive numbers-there are over 200 times more chickens killed each year than cows, and over 3,000 times more fish killed than cows (Faunalytics, 2020; Sentient Media, 2018; The Economist, 2011).

Several reasons for this relative neglect have been proposed. Generally, these small-bodied animals are viewed as less intelligent and less "like us" (Batt, 2009). For example, chickens lay eggs, as do most fish. Chickens have beaks. Fish don't breathe air. These differences are thought to make the suffering of these animals seem more distant from our own, and therefore make care and empathy for them less likely.

The current study was created to help answer important questions regarding these animals: which beliefs do the public have about small-bodied animals, and which of these are associated with animal-positive behaviors? Specifically, we looked at how a number of beliefs related to both a willingness to sign a petition to reduce the suffering of each animal and a diet pledge to reduce the consumption of each. We believe that by answering these questions, advocacy efforts can become more targeted and effective.

That said, this is just the first step in our program of research dedicated to Reducing Fish and Chicken Suffering. We will build on these preliminary results and see if they can be used to help animals. For example, future studies may investigate whether we can shift any of these beliefs in order to help small-bodied animals.

\section{Key Findings}

1. Some pro-animal beliefs are already reasonably common--for example, most people understand that air and water quality are important to chickens and fish. These findings suggest that education on these topics is probably not needed, but that these beliefs can be invoked as necessary. For instance, showing people pictures of dirty farm living conditions may be effective in shifting perspectives further.

2. The beliefs that had the largest correlations with signing a pledge to reduce fish consumption were that fish are more intelligent than people give them credit for, 


\section{faunalytics}

that many farms have horrible living conditions, and that fish are loving. Focusing advocacy efforts on bolstering these fish-related beliefs may be the most effective way to obtain dietary pledges to reduce consumption.

3. The beliefs that had the largest correlations with fish welfare petition signatures were that they are more intelligent than people give them credit for, that they are beautiful, and that many fish farms have horrible living conditions. Advocates working on petitions for fish welfare may want to incorporate these themes in their messaging and presentation.

4. The beliefs that had the largest correlations with signing a pledge to reduce chicken consumption were that chickens are beautiful, that they need room to explore and exercise, and that they are loving. Those trying to get people to reduce their consumption of chicken may want to focus on these themes.

5. The beliefs that had the largest correlations with chicken welfare petition signatures were that chickens need room to explore and exercise, that many chicken farms have horrible conditions, and that chickens are more intelligent than most people give them credit for. Advocates working on corporate campaigns may find messaging around these beliefs leads to an increase in petition signatures for chicken causes.

6. People were more likely to sign the petition than to take the dietary pledge. People were more likely to sign a petition that calls for welfare reforms than to take the diet pledge to reduce their own consumption. We also found that people who eat more of each animal were less likely to take the diet pledge to reduce their consumption than those who eat less already. However, these high consumers were no less likely to sign a petition to help improve conditions.

\section{Recommendations}

1. Try messaging around the top beliefs to see if you can improve your advocacy efforts. Based on these findings, messaging around the personality, emotions, suffering, and intelligence of these animals will likely lead to the best results, even outside of the context of diet pledges and welfare petitions. Slightly different beliefs were also important for each animal and each outcome. Therefore, we'd suggest focusing on the strongest messages in each group of beliefs, trying them out, and keeping track of their effectiveness in order to get the best results! 


\section{faunalytics}

2. Try stacking your asks. People were more likely to agree to sign a petition than to take a diet pledge to reduce their consumption. If you have interest in both outcomes, try asking for the petition signature first, and then go for a diet pledge after they've signed the petition. This may help increase diet pledges due to something known as "behavior consistency"-people generally want to be consistent in what they do, so following one successful ask with another related ask may increase uptake. Be careful to avoid overloading people with requests, though.

\section{Check back for more recommendations and data from other countries as our} program of research focusing on chickens and fish continues. We plan to examine these beliefs in other countries, and then to use experimental research to provide stronger recommendations about how these beliefs can be leveraged to alter behaviors. Although we have provided preliminary recommendations in this report, an experimental comparison of the most common and strongly associated beliefs is needed to see which can be used most effectively. Stay tuned for more from our line of research into small-bodied animals!

\section{Research Team}

This project was completed by Tom Beggs and Jo Anderson. We are grateful to our donors for funding this work, and indebted to the advocates who provided ideas on what beliefs people hold about these animals. Thanks to Thomas Billington and Haven King-Nobles from the Fish Welfare Initiative, Susanna Lybæk from the Norwegian Animal Protection Alliance, and Yip Fai Tse from Mercy For Animals. 


\section{faunalytics}

\section{Method Overview}

We began this line of research by asking advocates working in the small-bodied animal space what beliefs they think people hold about fish and chickens. In addition, we surveyed the general public and asked them to tell us their own beliefs about either chickens or fish $(n=126$; recruited through Positly). From these two sources, we compiled a list of possible beliefs for inclusion in the main study. We organized the list into themes and selected what we thought were the most common and important beliefs for each-a total of 33 beliefs for fish and 32 beliefs for chickens.

We then surveyed 1,073 U.S. adults and randomly assigned them to either the chicken or fish version of the survey. We then asked them how much they agreed or disagreed with each of the beliefs for their assigned animal.

There were two outcome measures to get a sense of how each belief was associated with important behaviors relating to the welfare of each animal. In the "diet pledge" outcome measure, each participant was asked whether they would pledge to reduce their consumption of the respective animal. For example, those in the fish condition were asked "In recent years, many people have begun to reduce how much fish they eat, a pattern that is expected to continue. Will you pledge to reduce your own fish consumption?" If they agreed, they specified the amount they would limit themselves to and provided a digital signature.

In the "petition" outcome measure, participants were asked whether they were willing to sign a petition supporting better welfare for the animal in question. For example, people who did the chicken survey were asked "We would like to give you the opportunity to sign a petition that would encourage legal reforms to improve the lives of farmed chickens. Specifically, the petition is designed to build support for regulations that would ensure that chickens raised on farms would have improved living and slaughter conditions. Would you be willing to sign this petition?" Participants could select either "yes please" or "no thanks" in response.

These were presented at the end of the survey, where we thanked participants for their answers and said "Great, thank you! Before you finish, we have a couple of quick requests for you. You don't have to agree to either, but please answer each question." We made it clear to participants that their participation incentive did not rely on them signing either the diet pledge or the petition. The two outcome measures were counterbalanced, meaning that half the participants saw the petition first, and the other half saw the pledge first. 


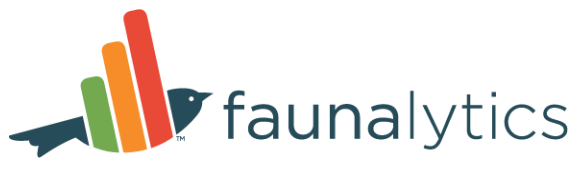

The above is a short overview of the study. Full procedural details and the survey instrument are available on our project page on the Open Science Framework. 


\section{faunalytics}

\section{Results}

As a note, because of the large sample size, many of the correlations were statistically significant. We recommend looking at the size of the correlation and the error bars to help understand differences between individual beliefs. For figures with error bars, the bars represent the $95 \%$ confidence intervals.

\section{How Many People Took The Pledge And Signed The Petition?}

$30 \%$ of participants took the diet pledge to reduce their consumption of fish, and $31 \%$ agreed to reduce their consumption of chicken. $37 \%$ of participants agreed to sign the fish welfare petition, and $40 \%$ agreed to sign the chicken welfare petition.

More specifically, of fish pledge-takers, $18 \%$ pledged to never eat fish, $72 \%$ pledged to eat it less than once a week, and $11 \%$ pledged to eat it 1-3 times a week. Of chicken pledge-takers, $8 \%$ pledged never to eat chicken, $60 \%$ pledged to eat it less than once a week, and $31 \%$ pledged to eat it only 1-3 times a week.

\section{The Most Common Beliefs About Fish \& Chickens}

The following figures show all of the beliefs included in the study and the proportion of people who either agreed or disagreed with each. This can give a sense of how common each of the beliefs are, which can be helpful in deciding which beliefs already exist and can be tapped into, and which beliefs need to be encouraged. 
Figure 1: Beliefs About Fish

Fish is a good source of protein Water quality isn't that important to fish -

Fish need room to explore and exercise Fish never find it stressful to be picked up or handled -

Fish can communicate with each other Fish can feel pain Fish are beautiful Fish mostly act out of instinct Fish can feel stress -

Fish are gross

Fish are curious -

Fish don't care about being over-crowded -

Fish can learn Fish play

Fish are contaminated with plastics, heavy metals, and chemicals -

Fish don't mind being in a barren environment

Individual fish don't have unique characteristics -

Fish can feel negative emotions like fear -

Fish don't care for their young

Many fish farms have horrible living conditions Fish are more intelligent than people give them credit for -

Most fish people eat are caught wild in the ocean -

Fish have no personality -

Big fish farms are gross -

Fish have a lower IQ than most animals

Fish are the healthiest animal to eat

Fish can feel positive emotions like pleasure -

Most farmed fish are raised inhumanely

Eating fish doesn't contribute as much to climate change -

Fish can bond with humans -

Fish are loving -

'Sustainable' products come from fish with good welfare

Fish are ethical to eat -

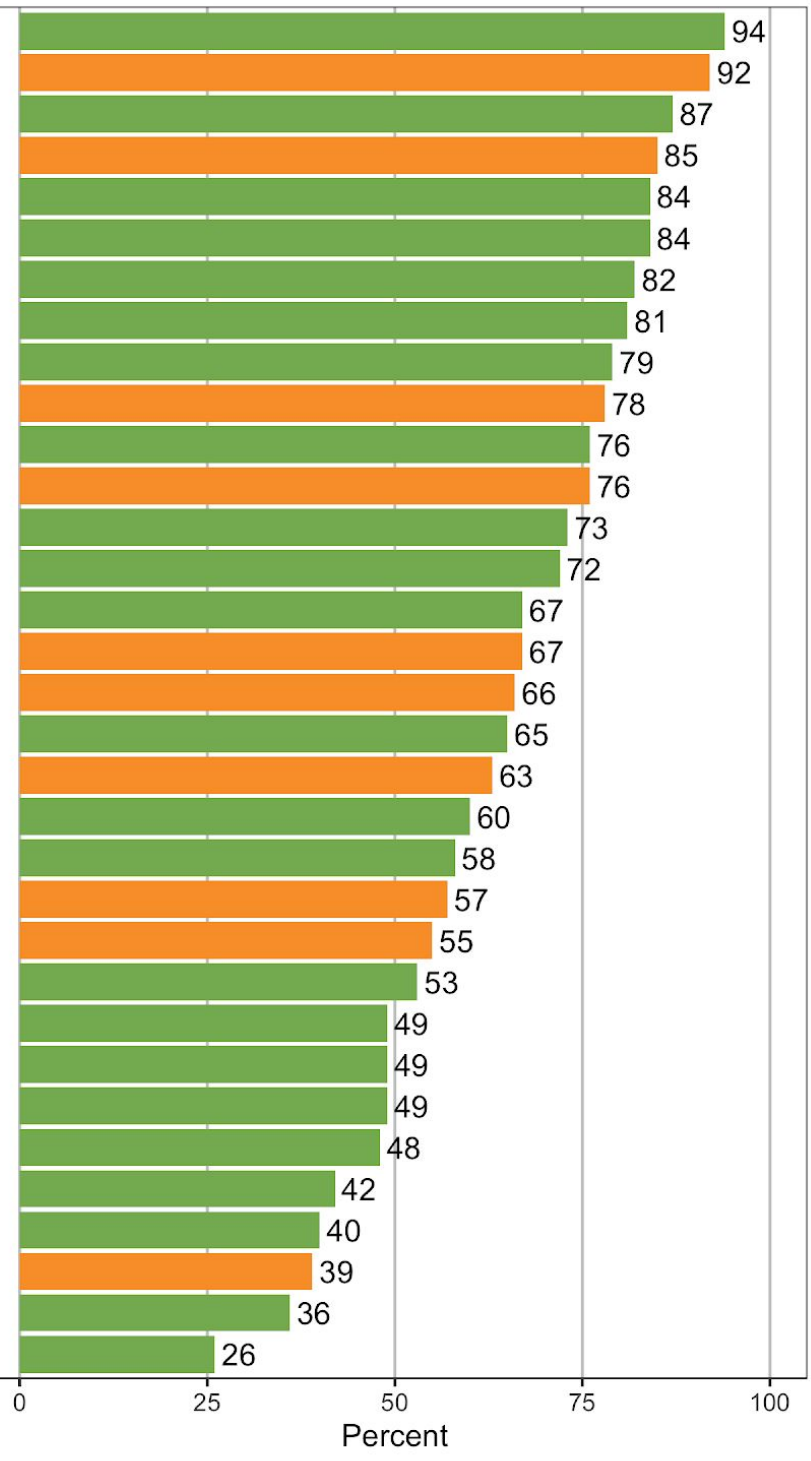

agree

disagree

Percent of respondents who agreed (or disagreed) with each of the fish beliefs 
Figure 2: Beliefs About Chickens

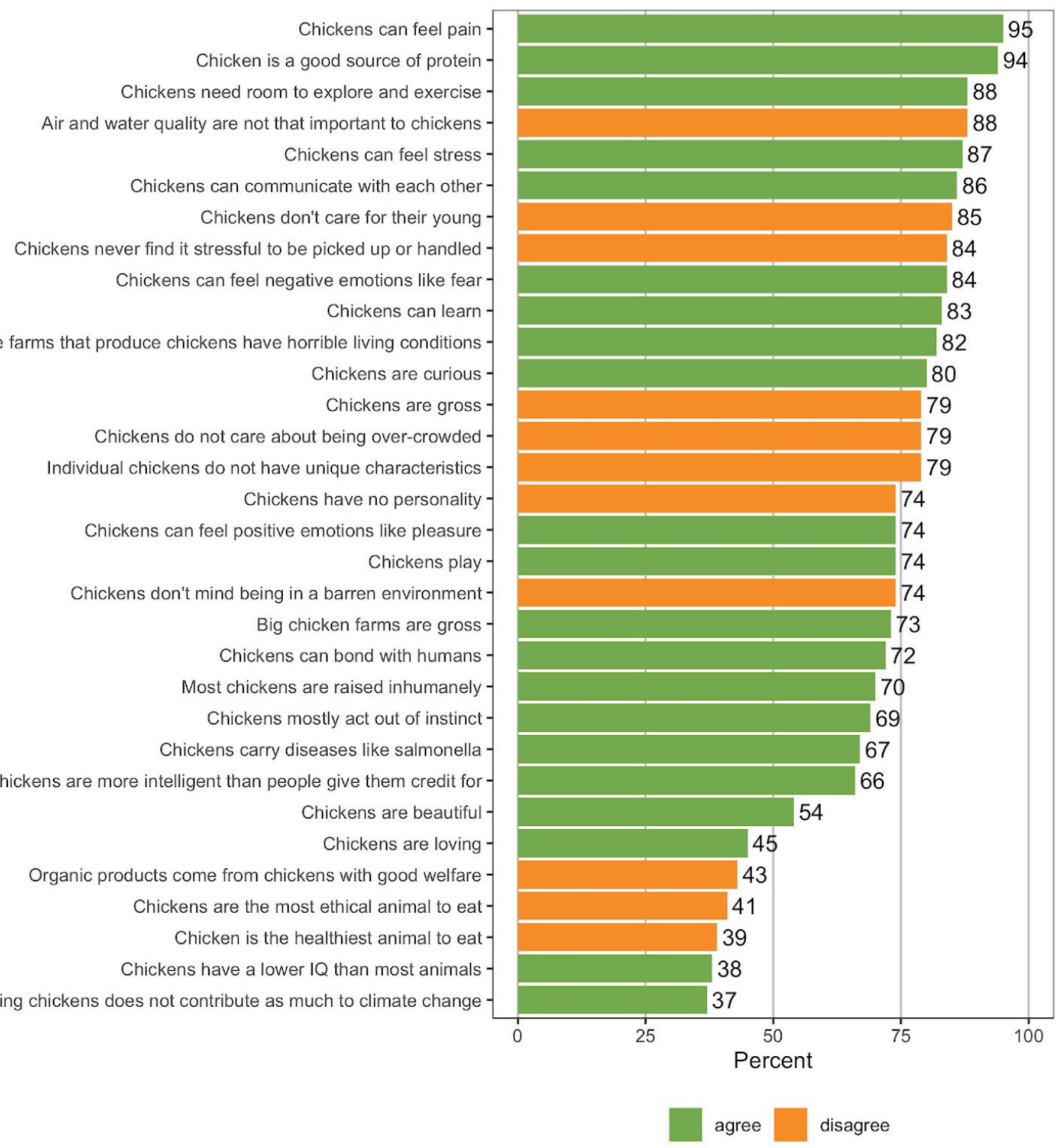

Percent of respondents who agreed (or disagreed) with each of the chicken beliefs 


\section{Which Categories Of Beliefs Were Most Strongly Associated With Animal-Positive Behaviors?}

Each individual belief is presented in the figures below, in groups of conceptually similar beliefs for each animal. The relative importance of each item within each group of beliefs can be seen for both petition signatures and diet pledges. We also discuss the top-performing individual beliefs across the categories. In general, average correlations for the beliefs in each category were small $(<.20)$, with beliefs generally showing larger correlations with diet pledges than with petition signatures.

Table 1 shows the average correlation between each group of beliefs and each outcome. This gives a sense of how the groups of beliefs compare to each other. Each group of beliefs is discussed in more detail below, while Table 1 allows for a bird's eye view of how they stack up. Bear in mind that this table is presented as a guideline only, because a group of beliefs may have a few very strong items that are diluted by a few weaker items, for example. Those stronger items still deserve attention.

Table 1. Average Correlations With Pro-Animal Behavior (Overall Rankings) 


\section{Correlation with Taking a Fish Diet Pledge (Strongest to Weakest)}
1. Fish Personality Beliefs
2. Fish Emotion Beliefs
3. Fish Suffering Beliefs
4. Fish Social Beliefs
5. Fish Intelligence Beliefs
6. Other Fish Beliefs
7. Fish Consumption Beliefs

\section{Correlation with Signing a Fish Welfare Petition (Strongest to Weakest)}

1. Other Fish Beliefs

2. Fish Personality Beliefs

3. Fish Emotion Beliefs

4. Fish Suffering Beliefs

5. Fish Intelligence Beliefs

6. Fish Social Beliefs

7. Fish Consumption Beliefs

\section{Correlation with Taking a Fish Diet Pledge (Strongest to Weakest)}

1 \& 2. Chicken Personality Beliefs / Chicken Emotion Beliefs (tie)

3. Chicken Intelligence Beliefs

4. Other Chicken Beliefs

5. Chicken Suffering Beliefs

6. Chicken Social Beliefs

7. Chicken Consumption Beliefs

\section{Correlation with Signing a Chicken Welfare Petition (Strongest to Weakest)}

1. Chicken Suffering Beliefs

2. Chicken Emotion Beliefs

3. Chicken Personality Beliefs

4. Chicken Intelligence Beliefs

5. Chicken Social Beliefs

6. Other Chicken Beliefs

7. Chicken Consumption Beliefs 
(Methodological note: See Supplementary Materials for more information and for tables showing the correlation averages and their standard deviation. Beliefs were grouped in rough categories, and some items may fit into more than one set of beliefs.)

\section{Beliefs About Fish}

\section{Fish Personality Beliefs}

Fish personality beliefs showed the largest average correlation with signing the diet pledge of all the categories of beliefs $(r=.20, S D=.05)$ and had the second strongest correlation with petition signatures $(r=.16, S D=.03)$. In other words, people who believe that fish have personality traits were more likely to take the diet pledge and sign the petition.

Looking at particularly strong individual items for both outcomes, people who believe that fish play and that they are loving were more likely to take diet pledges, while those who agreed with the idea that fish have no personality were less likely to sign the petition. 


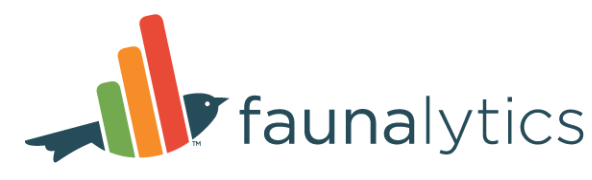

\section{Figure 3: Fish Personality Beliefs And Animal-Positive Behaviors}

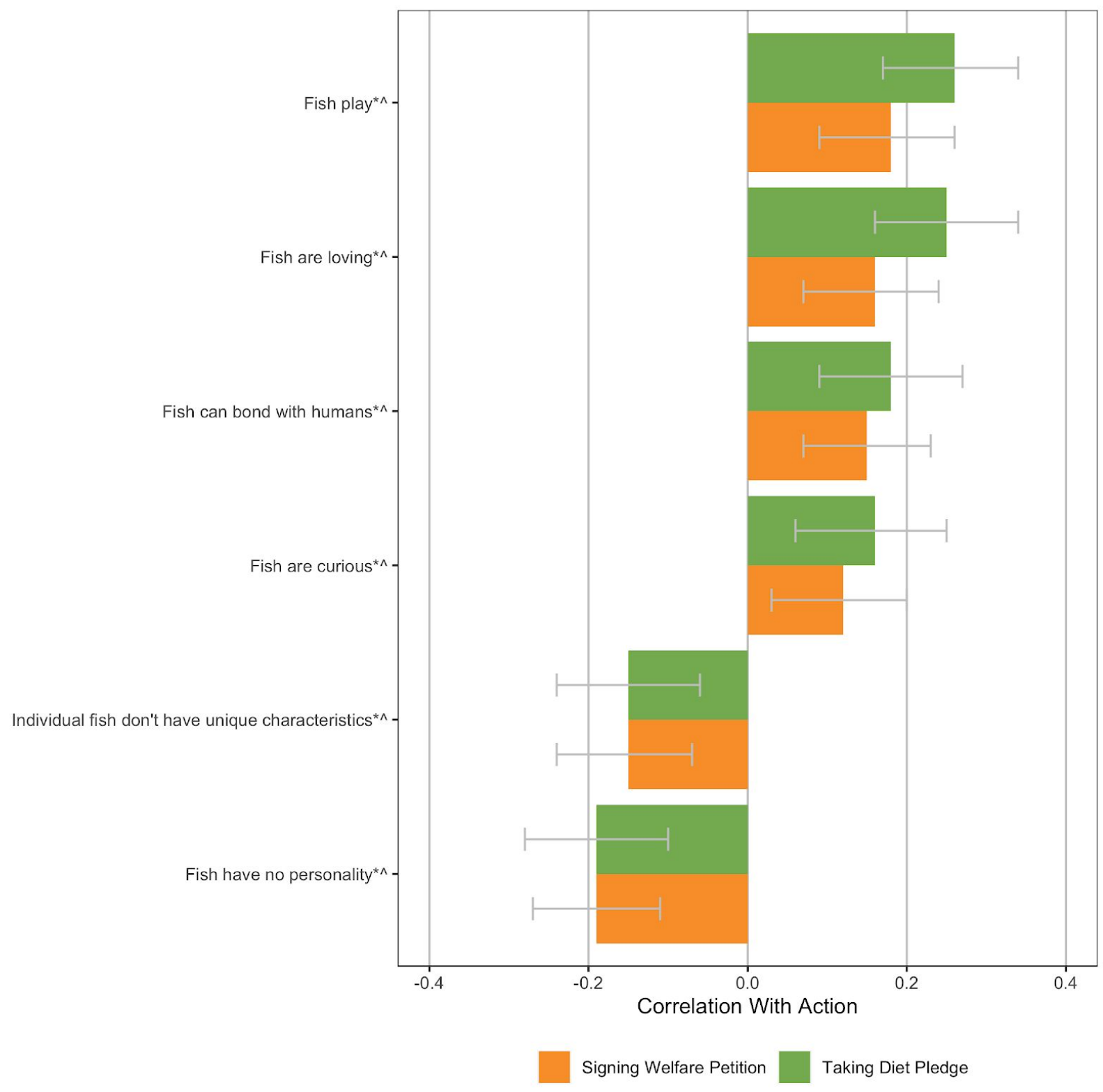

Note: '*' indicates that the correlation with petition signatures was significant, and ${ }^{\prime}{ }^{\prime}$ indicates that the correlation with diet pledges was significant

Beliefs around fish emotions had the second-largest average correlation with signing the diet pledge $(r=.18, S D=.03)$ and the third largest average correlation with petition signatures $(r=$ $.13, \mathrm{SD}=.02$ ). People who believe that fish have emotions were more likely to take the diet pledge and sign the petition. That said, no individual items in the emotion category were 


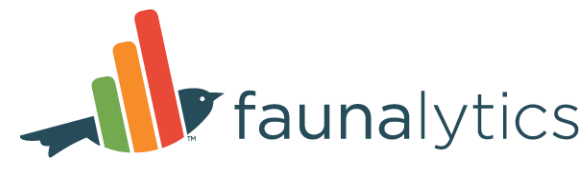

particularly strong when compared to beliefs across all categories. However, the category as a whole performed well and consistently, and should therefore likely be considered in advocacy efforts.

\section{Figure 4: Fish Emotion Beliefs And Animal-Positive Behaviors}

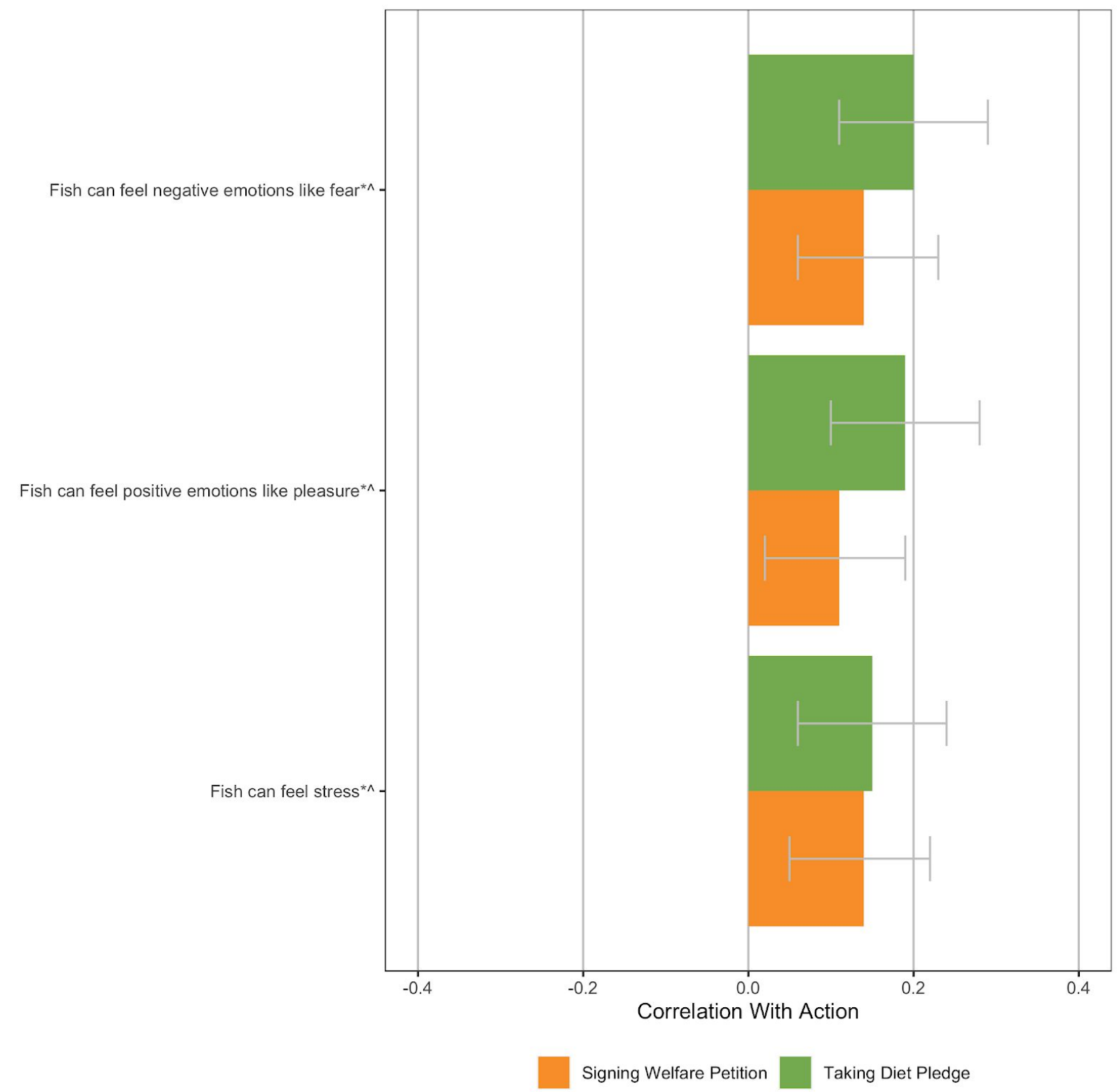

Note: '*' indicates that the correlation with petition signatures was significant, and ${ }^{\wedge}$ ' indicates that the correlation with diet pledges was significant 


\section{Fish Suffering Beliefs}

Beliefs around fish suffering had a good association with fish-positive behavior. Despite a large number of items in the category, it had the third largest average correlation with the diet pledge $(r=.16, \mathrm{SD}=.07)$ and the fourth largest association with petition signatures $(r=.13, \mathrm{SD}=.03)$. The belief that fish farms have horrible conditions was particularly strong-people who agreed were more likely to take the diet pledge and sign the petition.

This finding supports the common advocacy tactic of presenting information on farm conditions. Themes around grossness and inhumane treatment were also strong performers for diet pledges, while overcrowding and water quality performed well for petition signatures. 


\section{Figure 5: Fish Suffering Beliefs And Animal-Positive Behaviors}

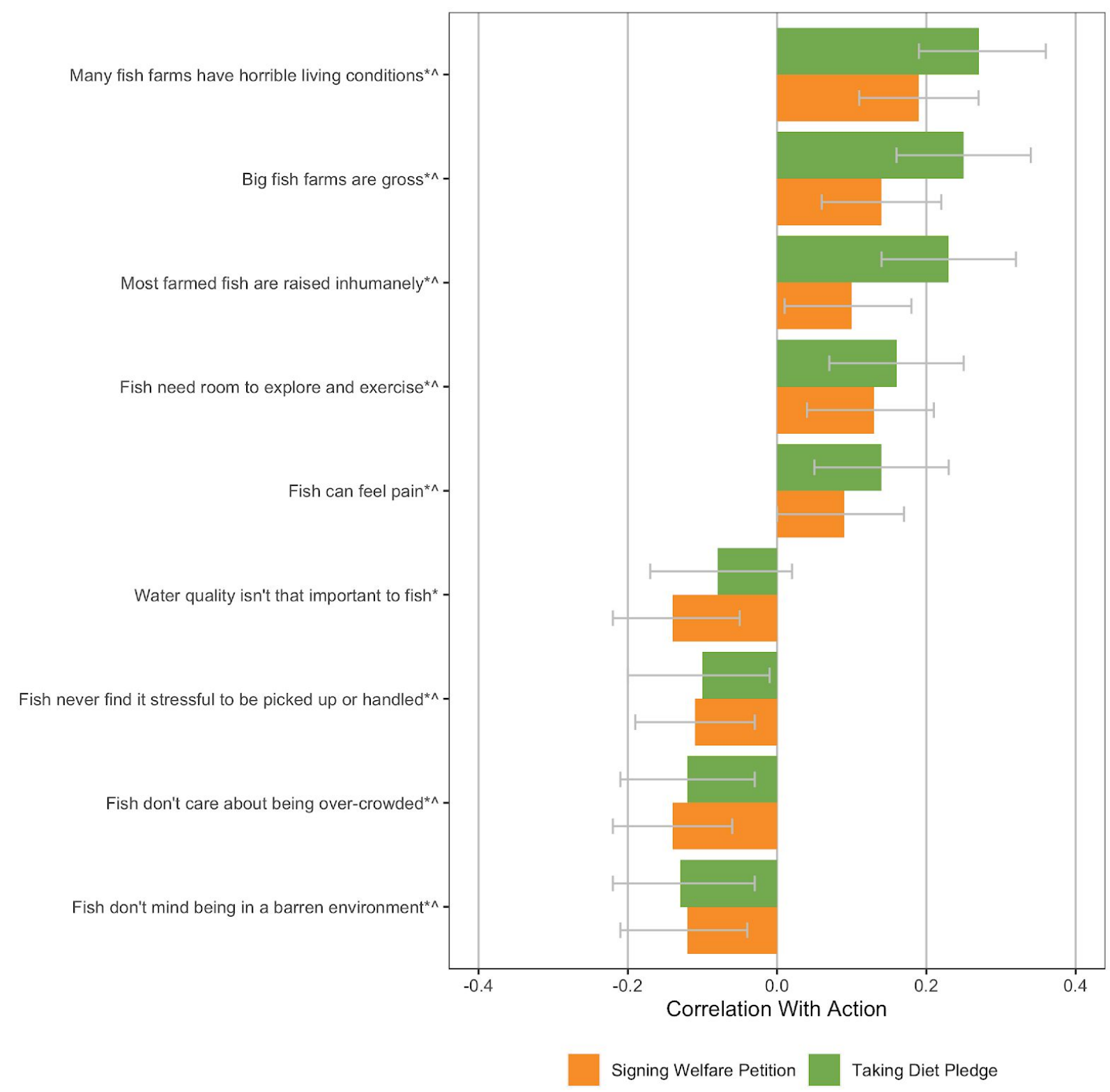

Note: '*' indicates that the correlation with petition signatures was significant, and ' ${ }^{\prime}$ ' indicates that the correlation with diet pledges was significant

\section{Fish Social Beliefs}

Fish social beliefs had the fourth-largest average association with dietary pledges $(r=.16, \mathrm{SD}=$ $.06)$ and the sixth largest association with petition signatures $(r=.10, \mathrm{SD}=.11)$. The belief that 


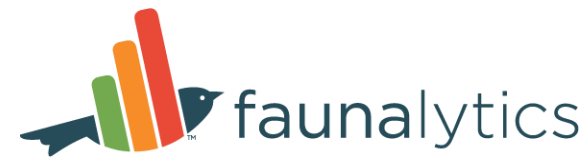

fish can communicate was one of the most important individual beliefs in terms of the association with petition signatures-those who agreed were more likely to sign the petition.

Figure 6: Fish Social Beliefs And Animal-Positive Behaviors

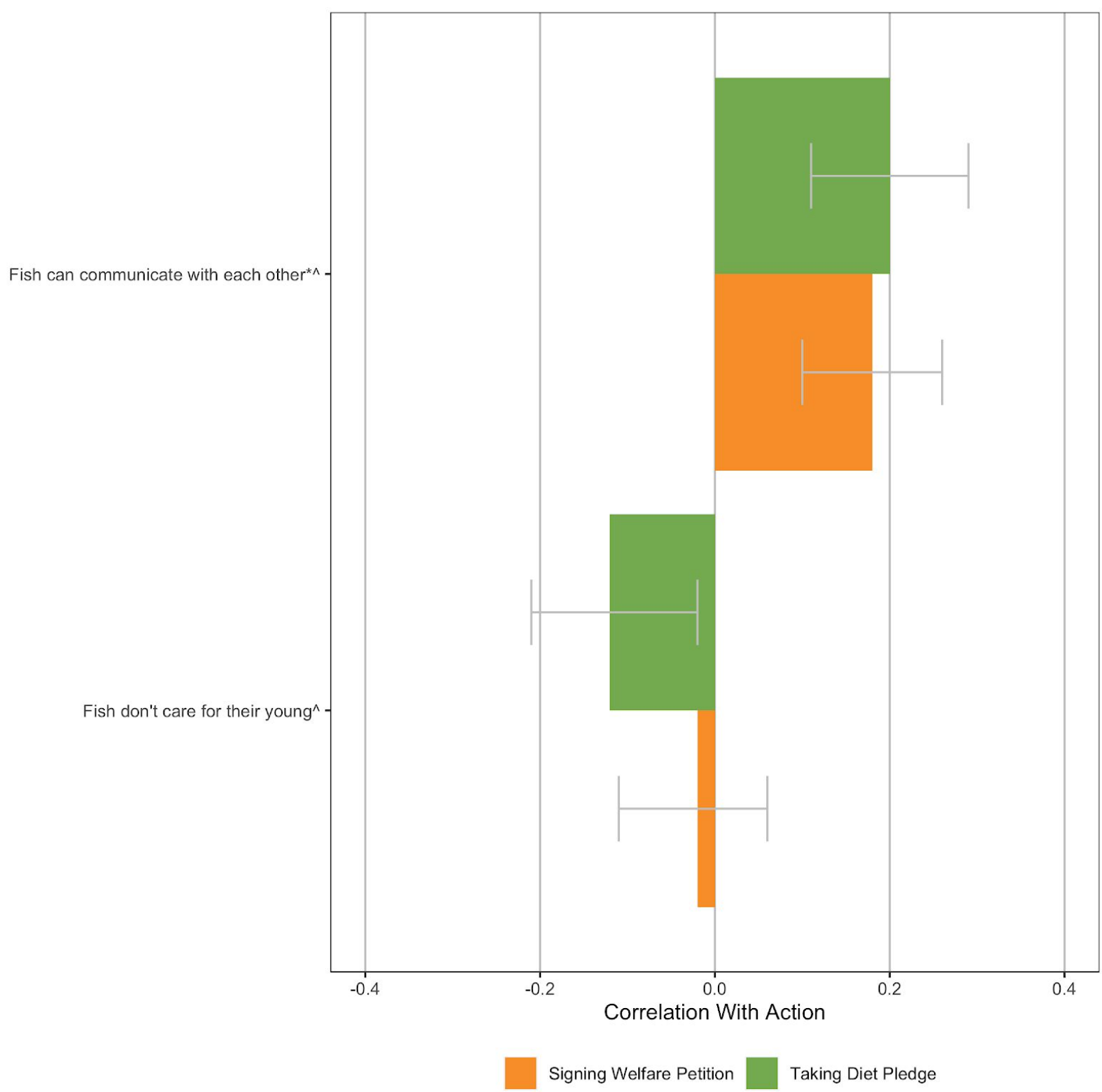

Note: ${ }^{\prime * \prime}$ indicates that the correlation with petition signatures was significant, and ' ${ }^{\prime}$ ' indicates that the correlation with diet pledges was significant 
Fish Intelligence Beliefs

Fish intelligence beliefs had the fifth strongest association with diet pledges $(r=.16, \mathrm{SD}=.09)$ and petition signatures $(r=.12, \mathrm{SD}=.10)$ on average. One item stood out from the rest-the belief that fish are more intelligent than people give them credit for. This item had the highest correlation of any individual belief in all categories for both diet pledges and petition signatures. Those who hold this belief were more likely to show both animal-positive behaviours in our study. 
Figure 7: Fish Intelligence Beliefs And Animal-Positive Behaviors

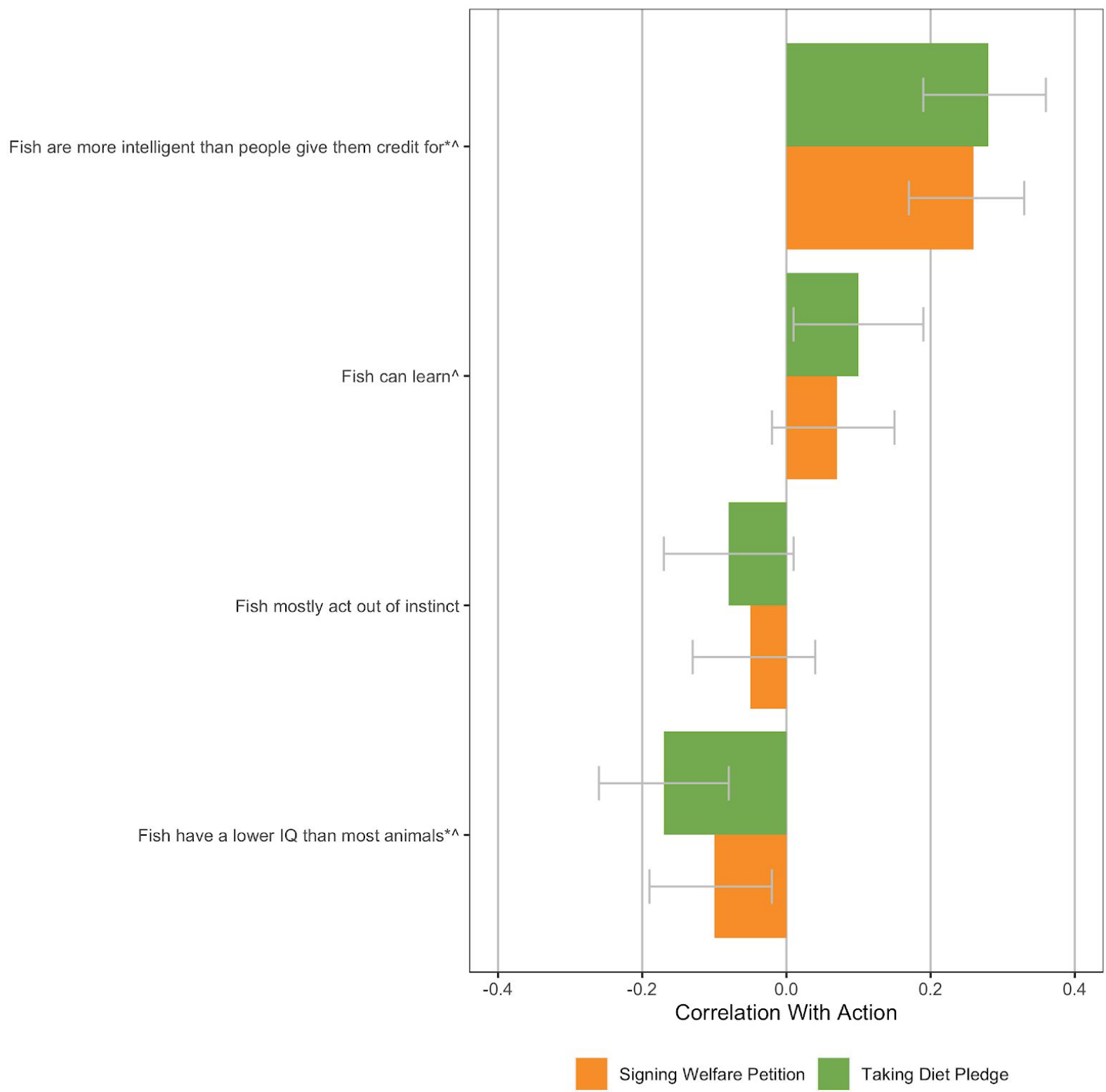

Note: '*' indicates that the correlation with petition signatures was significant, and ' $\mathrm{N}$ ' indicates that the correlation with diet pledges was significant 
Fish Consumption Beliefs

Beliefs relating to fish as food had the weakest performance of all of the categories of belief for both diet pledges $(r=.06, \mathrm{SD}=.03)$ and petition signatures $(r=.05, \mathrm{SD}=.04)$. No individual items particularly stood out when compared to other items across categories. 


\section{Figure 8: Fish Consumption Beliefs And Animal-Positive Behaviors}

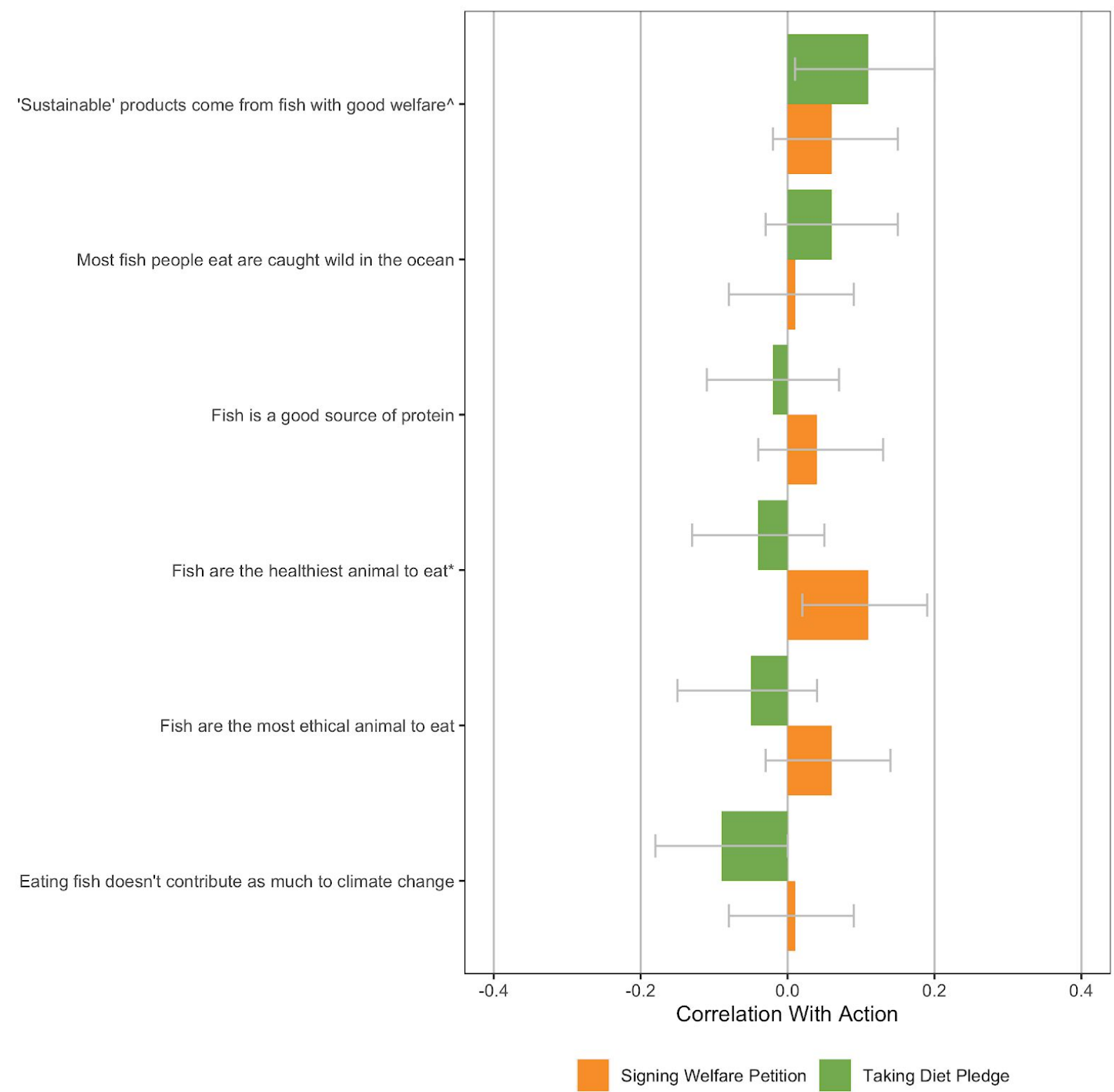

Note: '*' indicates that the correlation with petition signatures was significant, and ' ${ }^{\prime}$ ' indicates that the correlation with diet pledges was significant

\section{Other Fish Beliefs}

"Other" fish beliefs had only the sixth largest average correlation with diet pledges $(r=.12, \mathrm{SD}=$ $.07)$, but the largest average correlation with petition signatures $(r=.17, \mathrm{SD}=.07)$. This top category ranking for petition signatures was due in large part to the strong performance of the belief that fish are beautiful, which was one of the best performers in any category. 


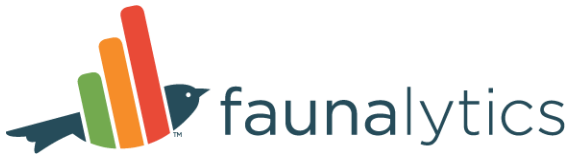

Figure 9: Other Fish Beliefs And Animal-Positive Behaviors

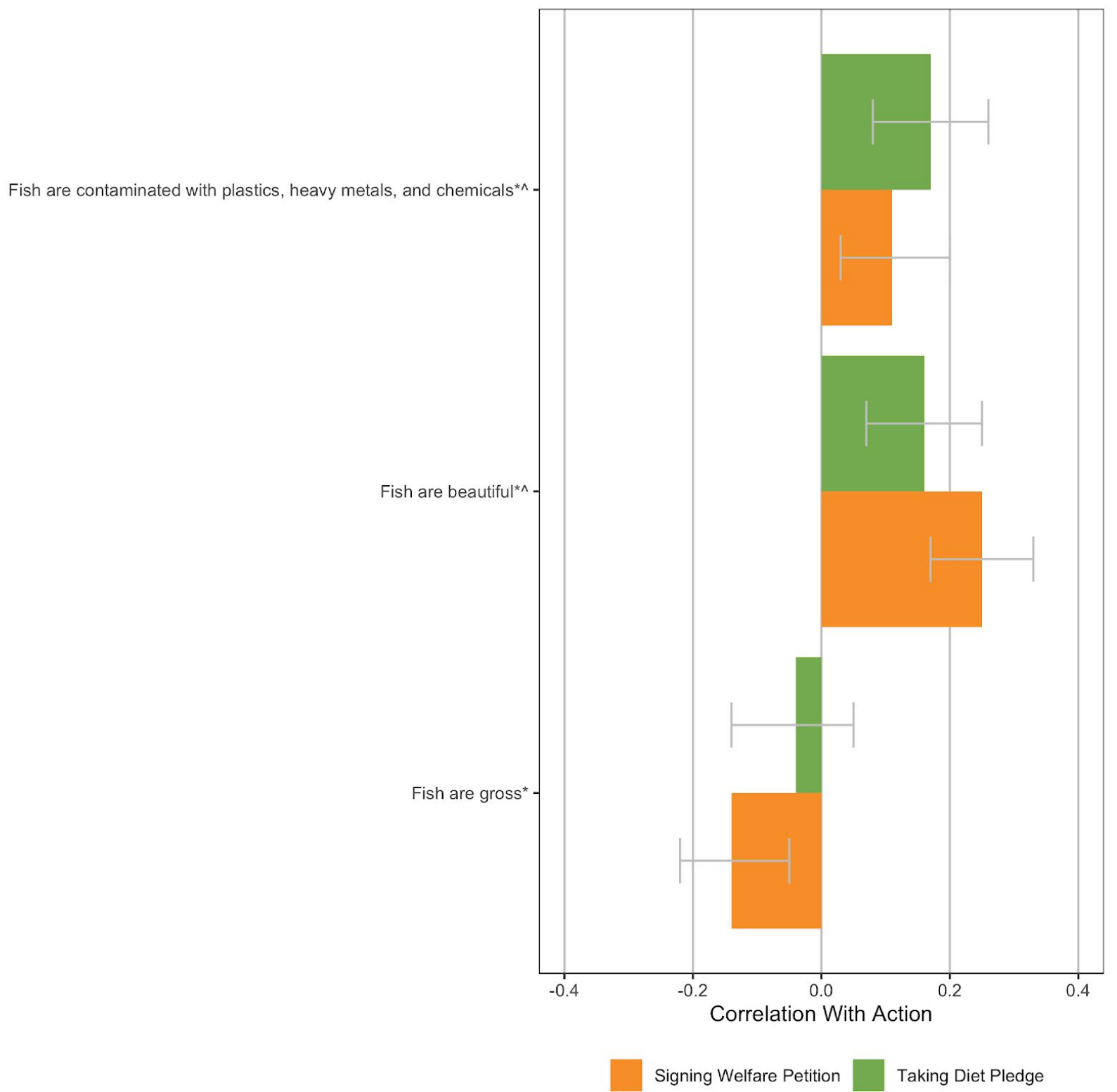

Note: '*' indicates that the correlation with petition signatures was significant, and ' ${ }^{\prime}$ ' indicates that the correlation with diet pledges was significant 


\section{-1) faunalytics}

\section{Beliefs About Chickens}

\section{Chicken Personality Beliefs}

Chicken personality beliefs had the largest average association with taking the diet pledge $(r=$ $.19, \mathrm{SD}=.03)$ and the third largest association with signing the petition $(r=.14, \mathrm{SD}=.03)$. People who agreed that chickens were loving were more likely to take the diet pledge, and the item was one of the strongest individual beliefs in the survey. The belief that chickens don't have unique personalities had a particularly strong negative association with petition-signing - that is, people who agreed with it were less likely to sign. 
Figure 10: Chicken Personality Beliefs And Animal-Positive Behaviors

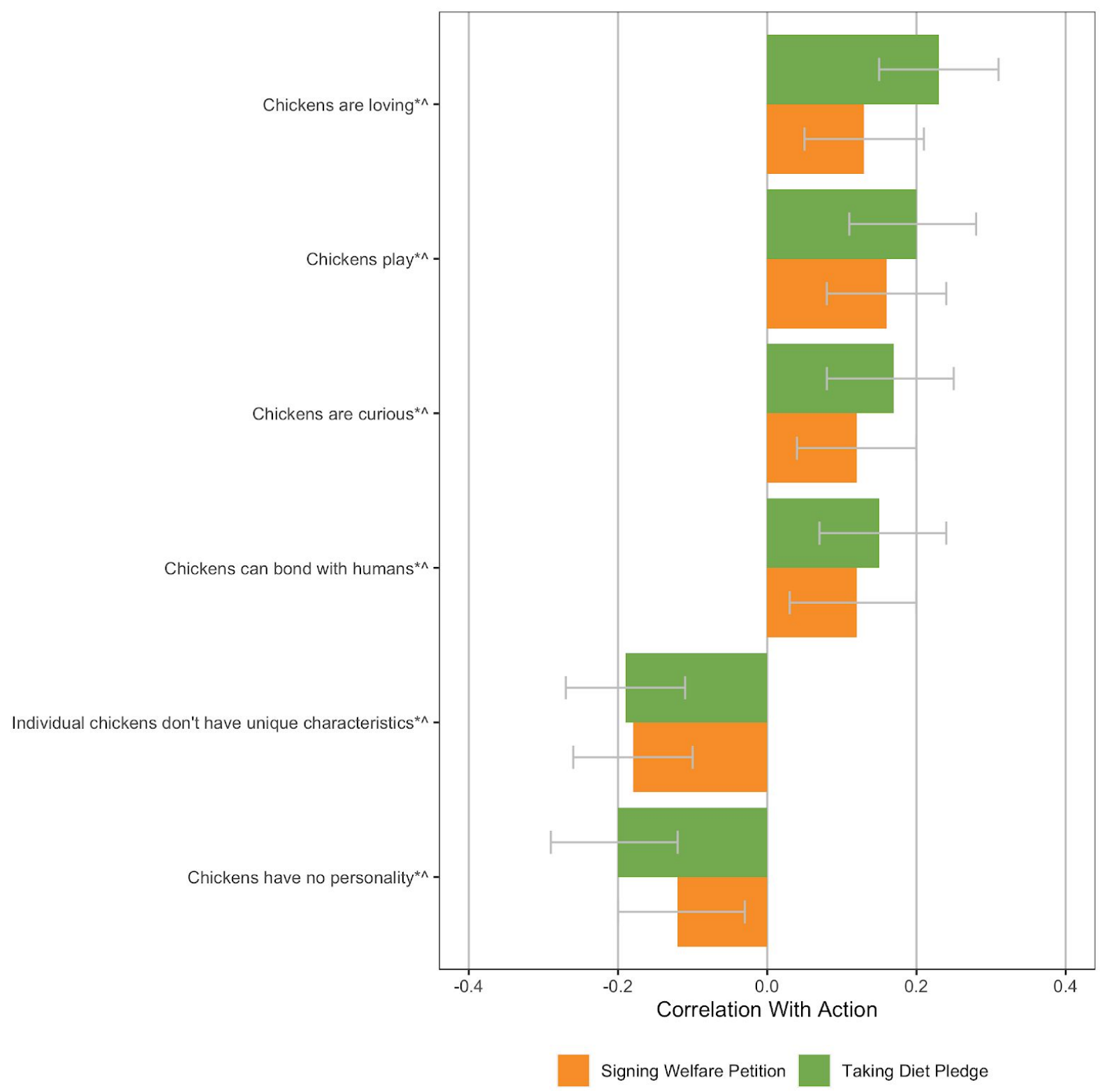

Note: '*' indicates that the correlation with petition signatures was significant, and ' ${ }^{\prime}$ ' indicates that the correlation with diet pledges was significant

\section{Chicken Emotion Beliefs}

Beliefs around the emotions of chickens were tied for top spot with personality in terms of the average correlation with taking the diet pledge $(r=.19, \mathrm{SD}=.02)$, and were second in terms of their association with the petition signatures $(r=.14$, SD $=.01)$. Similar to the fish emotions 


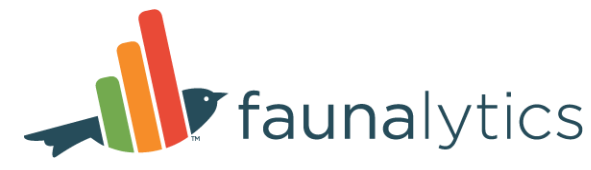

category, this was largely due to the consistency of the items in this belief category, as no single item performed particularly strongly. However, because the category as a whole performed well and consistently, it should likely be given consideration in advocacy efforts.

\section{Figure 11: Chicken Emotion Beliefs And Animal-Positive Behaviors}

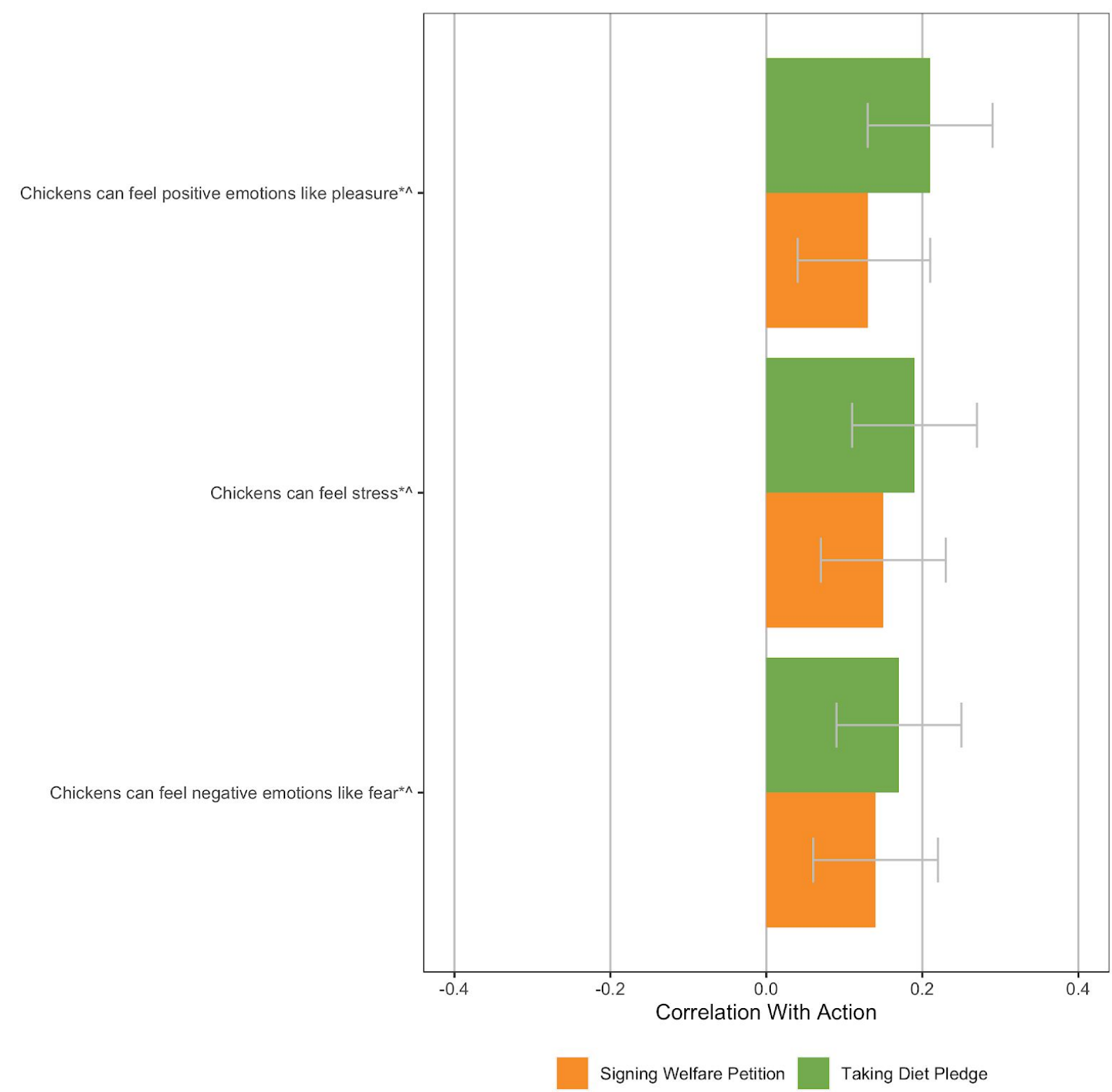

Note: '*' indicates that the correlation with petition signatures was significant, and ' $\mathrm{N}$ ' indicates that the correlation with diet pledges was significant 


\section{Chicken Suffering Beliefs}

While average chicken suffering beliefs were only the fifth strongest category for diet pledges $(r$ $=.14, \mathrm{SD}=.05)$, they were first for petition signatures $(r=.17, \mathrm{SD}=.04)$. This was on the strength of two items in particular, which had the strongest correlations across all items for chicken petition signatures: the belief that chickens need room to explore and exercise and that many chicken farms have horrible conditions.

These items are clearly important for petitions and should be considered by advocates using this approach. The belief that chickens need room to explore and exercise was also very strong among individual beliefs for dietary pledges. Based on these results, we feel that education on suffering is very likely to be important, particularly for petition signatures. 


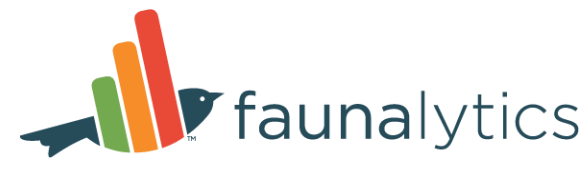

\section{Figure 12: Chicken Suffering Beliefs And Animal-Positive Behaviors}

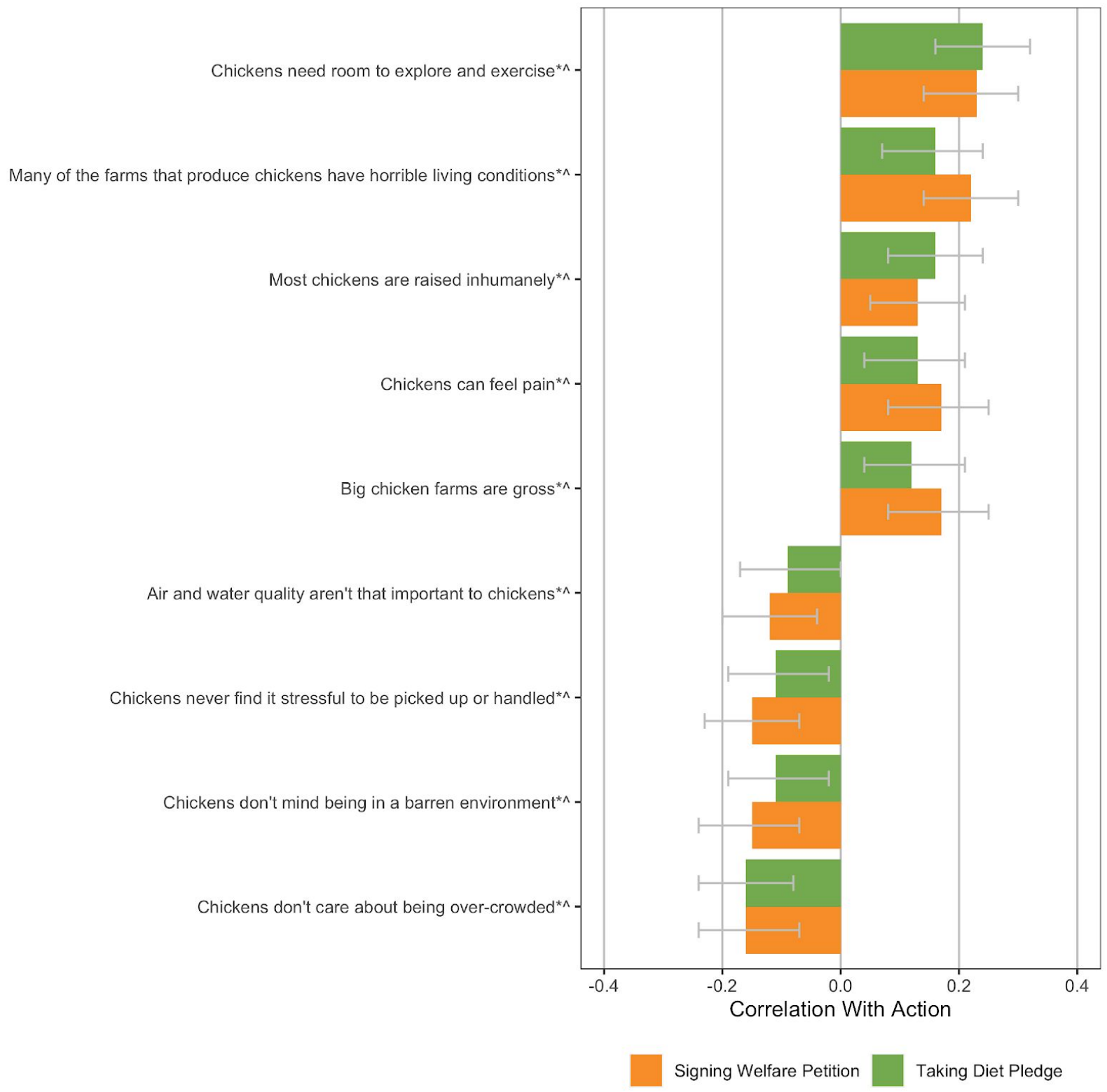

Note: '*' indicates that the correlation with petition signatures was significant, and ' ${ }^{\prime}$ ' indicates that the correlation with diet pledges was significant

\section{Chicken Social Beliefs}

Beliefs about the social nature of chickens had the sixth largest average association with diet pledges $(r=.13, \mathrm{SD}=.01)$ and the fifth largest association with petition signatures $(r=.10, \mathrm{SD}$ $=.01)$. Neither of the individual items particularly stood out. 


\section{Figure 13: Chicken Social Beliefs And Animal-Positive Behaviors}

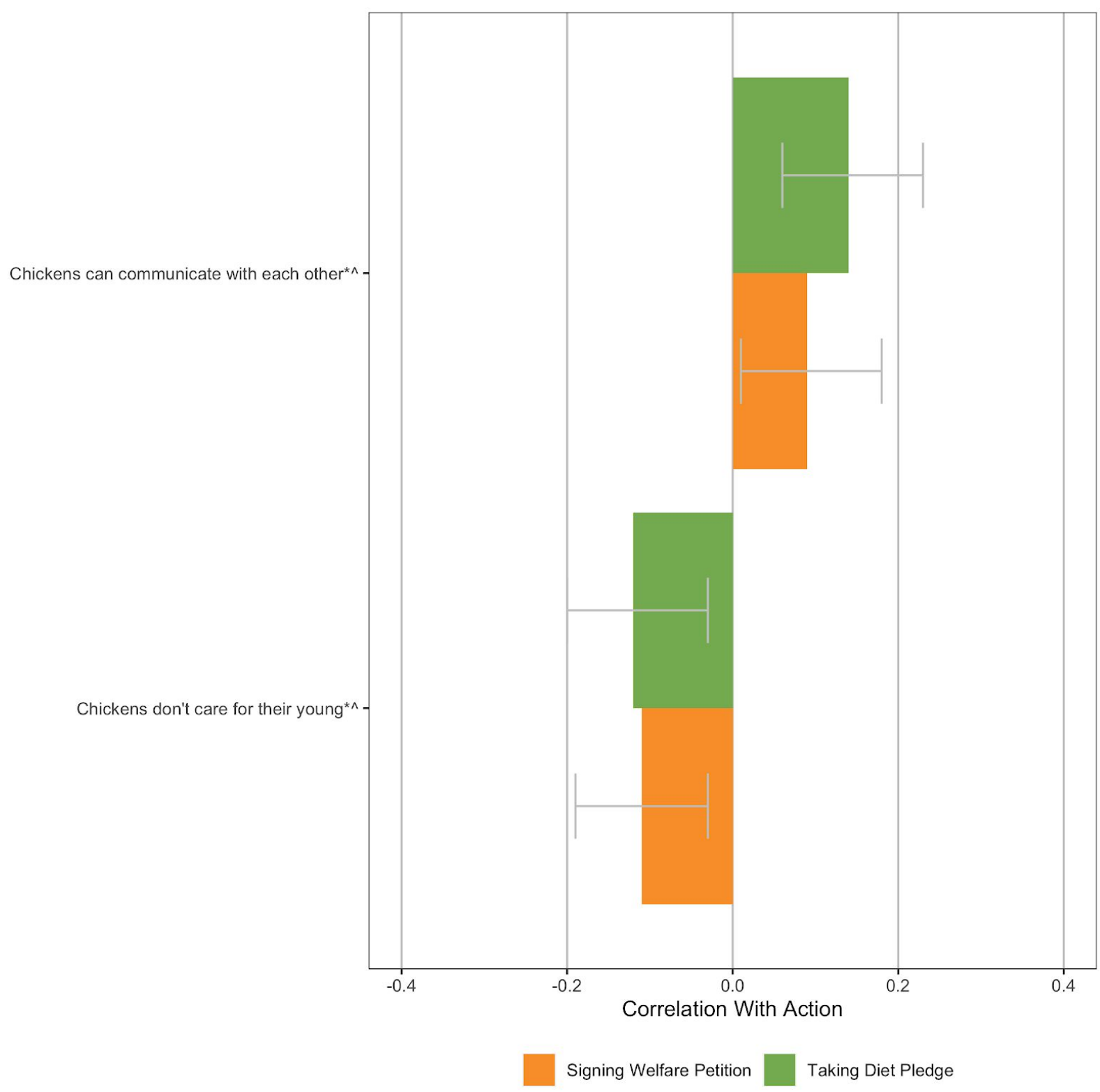

Note: '*' indicates that the correlation with petition signatures was significant, and ' $\mathrm{N}$ ' indicates that the correlation with diet pledges was significant 
Beliefs around chicken intelligence were third in terms of average correlation with diet pledges $(r$ $=.18, \mathrm{SD}=.06)$ and fourth in terms of petition signatures $(r=.12, \mathrm{SD}=.07)$. For diet pledges, two individual items stood out: beliefs about chickens being more intelligent than people give them credit for (which tended to be higher among those who signed the diet pledge) and the belief that chickens are less intelligent than other animals (which tended to be lower among those who signed the pledge). The belief that chickens deserve more credit for their intelligence was notably more prevalent among those who signed the petition. 


\section{Figure 14: Chicken Intelligence Beliefs And Animal-Positive Behaviors}

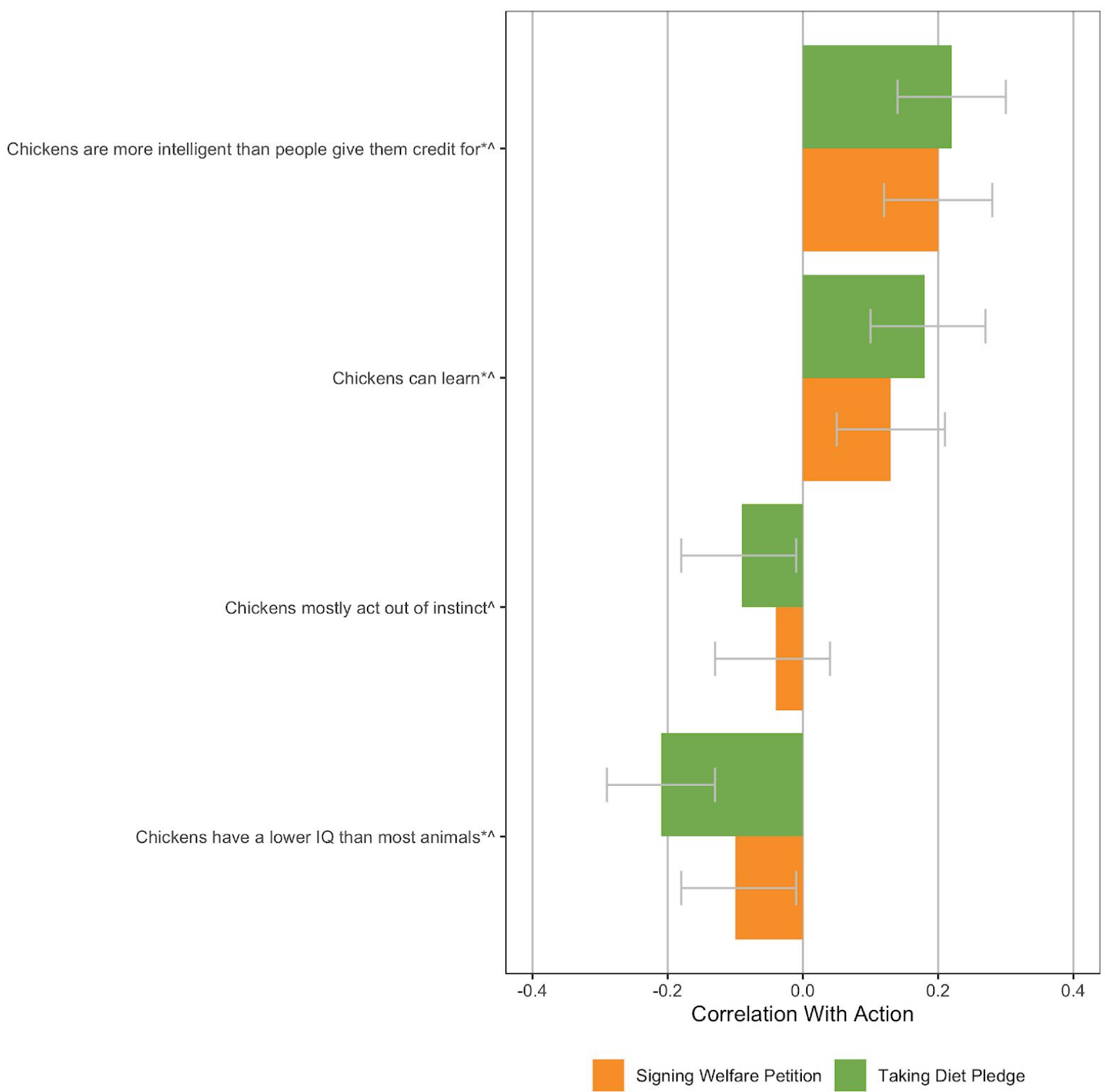

Note: '*' indicates that the correlation with petition signatures was significant, and ' $\mathrm{N}$ ' indicates that the correlation with diet pledges was significant 
Beliefs relating to chickens as food had the weakest average performance for both diet pledges $(r=.11, \mathrm{SD}=.08)$ and petition signatures $(r=.07, \mathrm{SD}=.05)$. However, one belief was notable: those who agreed that chicken didn't contribute as much to climate change as eating other animals were less likely to take the diet pledge. This belief had one of the largest associations with the diet pledge of all the individual beliefs and should therefore be given consideration. 


\section{Figure 15: Chicken Consumption Beliefs And Animal-Positive Behaviors}

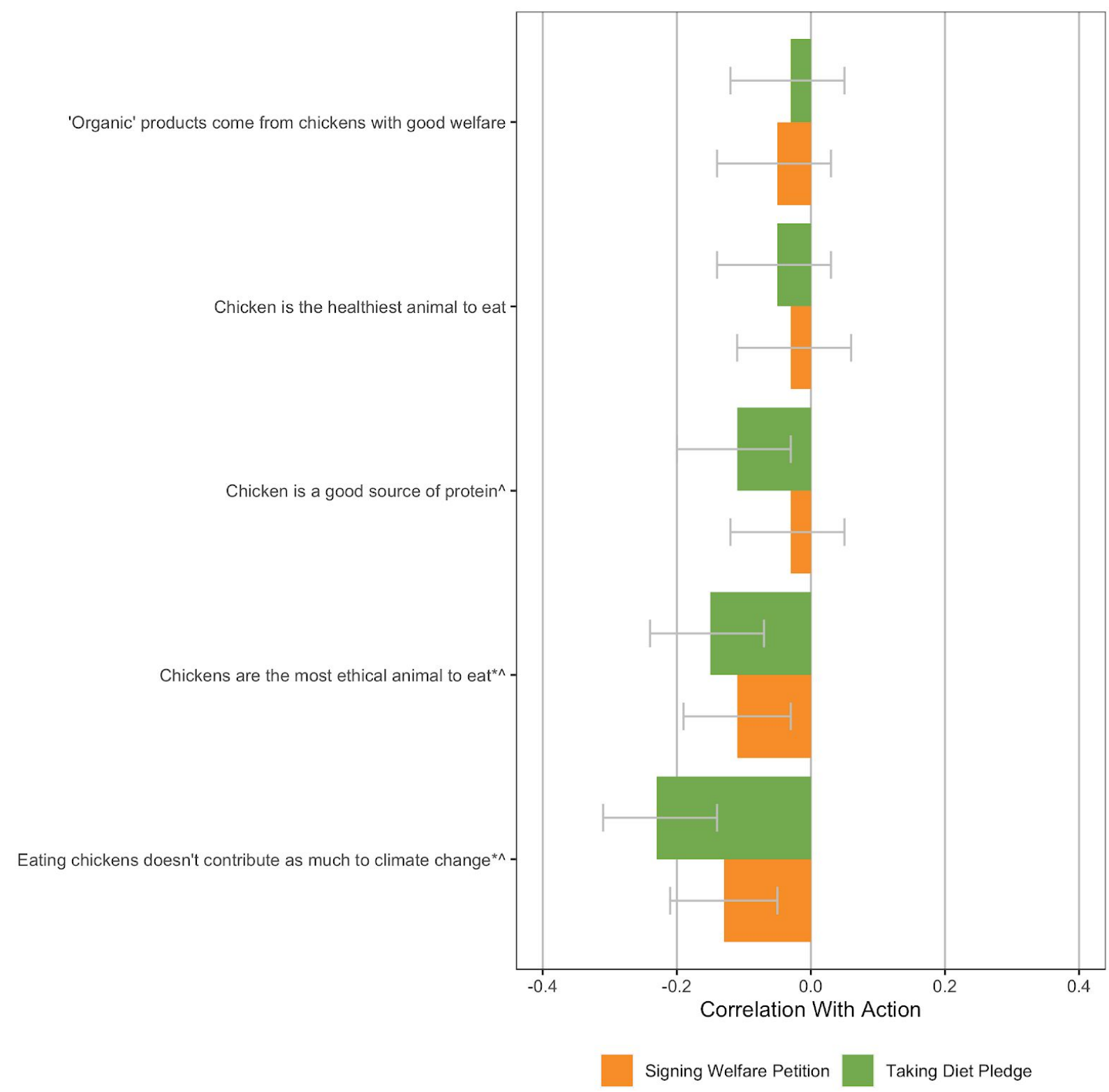

Note: '*' indicates that the correlation with petition signatures was significant, and ' $\mathrm{N}$ ' indicates that the correlation with diet pledges was significant 
Other Chicken Beliefs

Due mainly to the strength of one item-the belief that chickens are beautiful—the "other" category of beliefs was fourth in terms of average association with pledges $(r=.17, \mathrm{SD}=.13)$. In fact, this item had the largest correlation with diet pledges of any of the individual beliefs for chickens, and those who agreed were more likely to take the diet pledge to reduce their consumption. The category was less strongly associated with petition signatures, coming in sixth overall for petitions $(r=.10, \mathrm{SD}=.06)$. 
Figure 16: Other Chicken Beliefs And Animal-Positive Behaviors

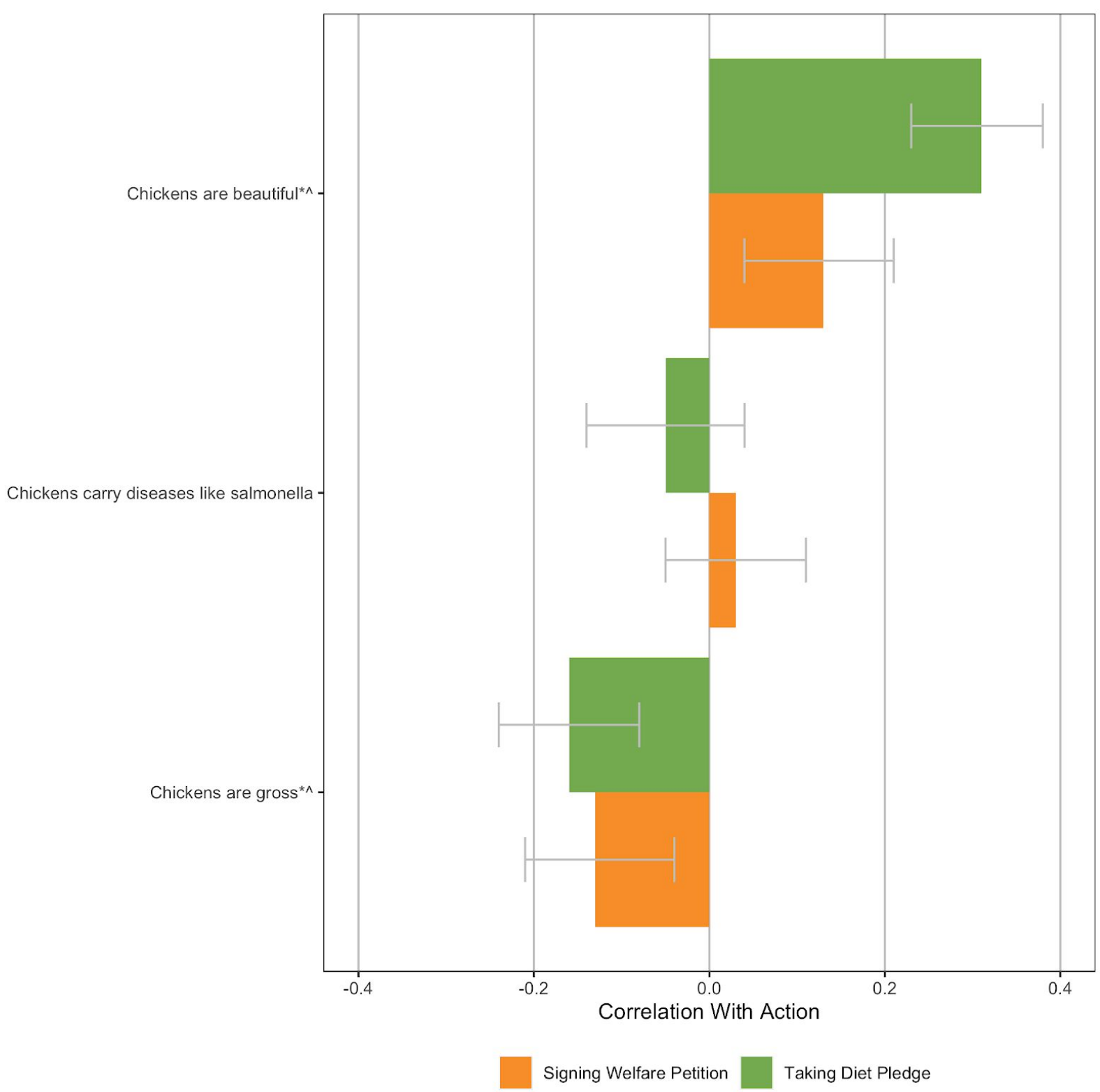

Note: '*' indicates that the correlation with petition signatures was significant, and ' $\mathrm{N}$ ' indicates that the correlation with diet pledges was significant 


\section{Pfaunalytics}

\section{What Role Did Participant Traits Play?}

Table 2 shows the rates of each pro-animal behavior for demographic groups that showed significant differences. Men were less likely to take either pledge or sign the fish petition, but there was no gender-based difference in chicken petition signatures. Those who had been fishing before were significantly less likely to take the pledges and to sign the chicken petition, but were slightly more likely to sign the fish petition. People who were the guardian of at least one companion animal were significantly more likely to show all of the animal-positive behaviors in the study. People with higher incomes were more likely to sign the fish pledge.

In terms of existing diet, those who ate more chicken were less likely to sign either diet pledge, and those who ate more fish were less likely to sign the diet pledge for fish (as a note, people who already abstained were not offered the diet pledge).

In addition to the characteristics shown in Table 2, we looked for differences based on geographical region (Northeast, Midwest, South, West), race (Caucasian/White, Black or African-American, Asian, Mixed-race or Other), age, education level, and whether participants had handled chickens before. There were no significant differences between groups, which means that the overall percentages should be used for all groups to avoid over-interpretation of non-significant differences. As a reminder, those percentages were as follows: $30 \%$ of participants took the diet pledge to reduce their consumption of fish, and $31 \%$ agreed to reduce their consumption of chicken. $37 \%$ of participants agreed to sign the fish welfare petition, and $40 \%$ agreed to sign the chicken welfare petition.

Table 2: Percent Who Took The Diet Pledge Or Signed The Petition Based On Group Membership 


\begin{tabular}{|c|c|c|c|c|}
\hline Characteristic & $\begin{array}{l}\text { Flsh Diet Pledges } \\
\text { (\%) }\end{array}$ & $\begin{array}{l}\text { Fish Petition } \\
\text { Signatures (\%) }\end{array}$ & $\begin{array}{l}\text { Chicken Diet } \\
\text { Pledges (\%) }\end{array}$ & $\begin{array}{c}\text { Chicken Petition } \\
\text { Signatures (\%) }\end{array}$ \\
\hline Gender & & * & * & * \\
\hline $\begin{array}{l}\text { Female or Other } \\
\text { Male }\end{array}$ & $\begin{array}{l}32 \\
28\end{array}$ & $\begin{array}{l}45 \\
30\end{array}$ & $\begin{array}{l}38 \\
26\end{array}$ & $\begin{array}{l}45 \\
36\end{array}$ \\
\hline Income & * & & & \\
\hline $\begin{array}{l}<\$ 24.9 \mathrm{k} \\
\$ 25 \mathrm{k}-49.9 \mathrm{k} \\
\$ 50 \mathrm{k}-74.9 \mathrm{k} \\
\$ 75 \mathrm{k}-99.9 \mathrm{k} \\
>\$ 100 \mathrm{k}\end{array}$ & $\begin{array}{l}22 \\
28 \\
32 \\
30 \\
35\end{array}$ & $\begin{array}{l}31 \\
37 \\
37 \\
41 \\
35\end{array}$ & $\begin{array}{l}30 \\
32 \\
31 \\
38 \\
24\end{array}$ & $\begin{array}{l}45 \\
41 \\
40 \\
30 \\
38\end{array}$ \\
\hline $\begin{array}{l}\text { Companion } \\
\text { animals? }\end{array}$ & * & * & * & * \\
\hline $\begin{array}{l}\text { Yes } \\
\text { No }\end{array}$ & $\begin{array}{l}32 \\
24\end{array}$ & $\begin{array}{l}39 \\
30\end{array}$ & $\begin{array}{l}33 \\
25\end{array}$ & $\begin{array}{l}44 \\
28\end{array}$ \\
\hline $\begin{array}{l}\text { Been fishing } \\
\text { before? }\end{array}$ & * & * & * & * \\
\hline $\begin{array}{l}\text { Yes } \\
\text { No }\end{array}$ & $\begin{array}{l}29 \\
33\end{array}$ & $\begin{array}{l}37 \\
36\end{array}$ & $\begin{array}{l}30 \\
37\end{array}$ & $\begin{array}{l}37 \\
50\end{array}$ \\
\hline $\begin{array}{l}\text { Fish consumption } \\
\text { (times per week) }\end{array}$ & * & & & \\
\hline $\begin{array}{l}\text { Never } \\
\text { Less than once } \\
1-3 \\
4-6 \\
7 \text { or more }\end{array}$ & $\begin{array}{l}43 \\
34 \\
22 \\
23 \\
22\end{array}$ & $\begin{array}{l}33 \\
36 \\
39 \\
46 \\
22\end{array}$ & $\begin{array}{l}34 \\
29 \\
34 \\
29 \\
11\end{array}$ & $\begin{array}{l}44 \\
39 \\
39 \\
27 \\
56\end{array}$ \\
\hline $\begin{array}{l}\text { Chicken } \\
\text { consumption } \\
\text { (times per week) }\end{array}$ & * & & * & \\
\hline $\begin{array}{l}\text { Never } \\
\text { Less than once } \\
1-3 \\
4-6 \\
7 \text { or more }\end{array}$ & $\begin{array}{c}56 \\
45 \\
28 \\
24 \\
9\end{array}$ & $\begin{array}{l}45 \\
43 \\
35 \\
35 \\
23\end{array}$ & $\begin{array}{l}62 \\
49 \\
30 \\
23 \\
21\end{array}$ & $\begin{array}{l}59 \\
48 \\
35 \\
42 \\
43\end{array}$ \\
\hline
\end{tabular}

Notes. An asterisk (*) indicates that there was a statistically significant difference between groups. 


\section{faunalytics}

\section{Conclusions}

This study was an important first step in understanding the beliefs people have about chickens and fish, and how they relate to pro-animal behaviors.

Overall, $37 \%$ of participants agreed to sign the fish welfare petition, and $40 \%$ agreed to sign the chicken welfare petition. In addition, $30 \%$ of participants took the pledge to reduce their consumption of fish, and $31 \%$ agreed to reduce their consumption of chicken. Therefore, a decent proportion of the sample was willing to agree to each ask, but a higher proportion was willing to sign the petition than to take the diet pledge. This makes sense, as it is a simple task that could be completed in a matter of seconds and didn't require any additional effort or follow-up like a personal change does.

\section{Which Beliefs Were Most Common?}

Animal advocates may wish to consider how to leverage the animal-positive beliefs that are already strongly held on average. Although education on these points may not be required because they are already prevalent, these beliefs may be useful to help drive change.

Figures 1 and 2 in the Results section are useful for identifying the most common beliefs. For example, most people agree that fish need room to explore and exercise. It is likely that showing data, images, or videos of packed aquaculture farms and then asking for a signature on a petition to reform regulations is an effective approach. This is especially true because in addition to being common, this belief was associated with petition-signing in the study.

However, just because a belief is common, that doesn't mean that everyone holds it. Some people may still need education on why room to explore and exercise is a good thing.

We found that in most cases general beliefs aligned with top-performing individual beliefs in terms of outcome; however, some beliefs that performed well based on outcome were generally not held. When a belief is positively correlated with pro-animal behavior but isn't held strongly by most people, it's a likely candidate for educational approaches to advocacy. For example, people seem to be somewhat less sure about chickens' IQs in comparison to other animals. Informing about chicken intelligence may be helpful in order to shift both beliefs and behavior, as we found that this belief was significantly correlated with both diet pledges and petition-signing. In these cases, education can be provided and then an action can be requested. 


\section{faunalytics}

In general, understanding the prevalence of various beliefs can help advocates target efforts based on where most people currently stand.

\section{Beliefs Most Strongly Associated With Pro-Animal Behavior}

\section{Groups Of Beliefs}

We presented the average correlation of the items in each group of beliefs along with Figures 3-16 above. Generally, each group of beliefs had some stronger and weaker items in it, so advocates would likely be wise to focus on the individual beliefs in each grouping that have the largest correlations.

Comparing across the categories suggests that if you're interested in diet pledges, you should focus on the personality and emotions of the animals. These groups of beliefs had the highest correlations with whether people took the diet pledge for both fish and chickens.

If you're interested in getting petition signatures, focusing on suffering for chickens and the personality and beauty of fish seem to be the categories that are most important. (The "other" group of beliefs was most strongly associated with fish-positive behaviors, although this was driven almost entirely by the "fish are beautiful" belief.) Highlighting the suffering of chickens may be especially important because of the growing number of people who are becoming aware of the conditions these animals are being raised in.

Beliefs related to the consumption of fish or chickens were less strongly associated with pro-animal behaviors than the other categories of beliefs. The exception was the belief that consuming chicken doesn't contribute as much to climate change-people who agreed were less likely to take the pledge. However, other beliefs around things like whether fish are caught wild or are a good source of protein and the relationship between organic farming and chicken welfare are likely not the most fertile ground for advocacy.

\section{Individual Beliefs}

Beliefs around poor living conditions were among those most important individual items for both chickens and fish and for both diet pledges and petition signatures. The common advocacy tactic of educating the public on these points is supported by this finding.

The beauty and intelligence of chickens and fish were also among the individual beliefs with the largest correlations with pro-animal behaviors. It may not be immediately clear how the beauty 


\section{faunalytics}

of a certain fish is related to how people view fish on commercial farms, or how a particularly beautiful chicken is related to a common broiler chicken raised in a massive, dirty barn.

However, research is showing that emotional reactions--like the feeling someone could get from seeing a particularly beautiful animal--can have an effect on judgments and decision-making (Angie, Connelly, Waples, \& Kligyte, 2011). A contrast effect could also potentially be useful, where the animal's potential is contrasted with the reality on industrial farms. For instance, advocates could compare images of wild rainbow trout with those raised on farms or rescued broiler chickens to those from industrial warehouses. We may investigate questions such as these in future research.

Based on other particularly strong items, showing fish playing, or educating people on the love lives of fish-like the fact that some fish react emotionally after losing a mate (Vox, 2019) -are potentially useful avenues as well.

Finally, the single most strongly-related item for both the diet pledges and petitions for chicken welfare was "Chickens need room to explore and exercise." While it is likely that many people have seen images of crowded chicken barns by now, using these images as reminders may be useful to help nudge people in the right direction before making an animal-positive ask.

\section{Additional Beliefs Of Interest For Diet Pledges}

The belief that fish farms are gross was one of the beliefs most strongly associated with pledging to reduce fish consumption. This is likely associated with other suffering-related beliefs that also performed well, and suggests that it may be useful to emphasize this suffering to fish consumers. In line with this idea, one study found that people would be more likely to stop eating at a restaurant if the restaurant's fish came from poor-quality water than if it came from an overcrowded environment or and questionable breeding and handling practices (Caldwell. 2017). While this prioritization may be driven by self-interest around food safety and quality, it can be used strategically to help decrease suffering. This is because people tend to refer back to their past behavior when making choices in the present (Albarracin \& Wyer, 2000). As a result, if someone signs a welfare petition, it is an animal-positive behavior that they may remember in the future. This can influence them to make other animal-positive changes in their lives, even if the initial behavior was more self-serving.

The idea that chickens are loving was strongly associated with taking the diet pledge. Therefore, advocates who are particularly interested in getting dietary pledges may be well-served to highlight the loving nature of chickens_-both their affectionate interactions with other chickens and with humans would likely serve well here. 


\section{faunalytics}

Results suggested that a belief that chicken consumption isn't as bad for the environment was particularly important. It is true that chickens produce less greenhouse gas per pound than beef or pork (Environmental Working Group, 2011), and those who agreed with this more were less likely to sign the chicken diet pledge. Therefore, highlighting another disparity in greenhouse gas production - the differences between chicken and beans or lentils-may be a worthwhile strategy for those who are concerned with this aspect of consumption.

\section{Additional Beliefs Of Interest For Petition Signatures}

The idea that fish have no personality was one of the beliefs most strongly associated with petition signatures - those who agreed more were less likely to sign. One way to address this belief might be to show how different fish of the same species use different behaviors and strategies to solve the same problem. For example, educating people about things like individual differences in bravery (The Independent, 2017) could help to create more appreciation for the uniqueness of fish.

The idea that chickens can feel pain was among the beliefs most strongly associated with signing a welfare petition. Combined with the themes of needing space and living in horrible conditions, this suggests that advocates who lobby the public for chicken welfare improvements may want to continue to focus on the suffering of these animals. The grossness of big farms, barren conditions, overcrowding, and the ability to feel stress were all concepts that were strongly associated with petition signatures.

\section{Participant Characteristics}

As shown in Table 2, we found some differences in behavior between people with different diets. Specifically, people who eat more chicken were less likely to sign the chicken reduction pledge and the fish reduction pledge. People who eat more fish were less likely to sign the fish reduction pledge, but not the chicken reduction pledge. (Note that people who already did not eat the respective animal were excluded from analyses. Based on how often people said they ate each type of animal product, the sample was $1 \%$ vegan and $3 \%$ vegetarian.)

On the other hand, neither fish nor chicken consumption was associated with participants' willingness to sign either welfare petition. This suggests that while many frequent consumers are not willing to reduce their own intake, they may still support institutional advocacy efforts. 


\section{faunalytics}

Participants with higher incomes were significantly more likely to sign the fish reduction pledge than those with lower incomes. However, they were no more or less likely to sign the chicken pledge or either petition, so this association may have arisen by chance (as we would expect to see more of a pattern). If not, it is possible that people with higher incomes have more options, as plant-based alternatives often carry a cost premium over the equivalent animal product.

We found some significant differences based on self-identified gender. Men were less likely to sign both diet pledges and the fish petition than women or people of other genders, while all genders were equally willing to sign the chicken petition. Women have been found to be more likely to show animal-positive behaviors in many other studies as well.

We also asked participants about previous life experiences that may affect their beliefs about chickens and fish. Specifically, we asked whether they had ever gone fishing and whether they had ever handled chickens.

People who had handled chickens versus people who hadn't did not differ in their likelihood of signing either pledge or petition. However, people who had been fishing were more likely to sign the fish welfare petitions than those who had not. At the same time, they were less likely to take either diet pledge or to sign the chicken petition than those who had not been fishing.

This again suggests that some people support animal welfare improvements but do not want to change their own behavior. As such, advocates may want to consider offering a petition or similar advocacy action to those who are not interested in taking a diet pledge.

We found no significant differences in whether people signed the petition or pledged to change their diet based on their geographic location in the US, age, race, or education level.

\section{Interpretation And Future Directions}

While the above analyses provide important clues, more research is needed to demonstrate whether these beliefs are useful in actually shifting animal-positive behaviors, or whether they are simply associated with diet pledges and petition signatures. In other words, can the beliefs be shifted to bring about behavior change, or are they only correlated with behavior because people who care about animals already hold those beliefs?

We plan to follow this study up by replicating it in additional countries. This will give us a sense of the beliefs that are held in other cultural contexts. We will also be designing an intervention that will attempt to use some of the beliefs that appear most important based on this research to try and increase animal-positive behaviors. This will likely take the form of an experiment 


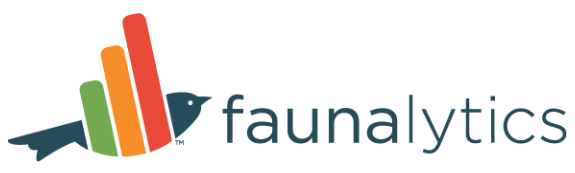

(randomized controlled trial), where different groups of people are shown an intervention based around different beliefs to see if any of them influence animal-positive behaviors. 


\title{
faunalytics
}

\section{Supplementary Materials}

\section{Method: Additional Details}

\author{
Participants And Power
}

All participants were recruited through Positly, a company that screens out answers that may be fraudulent or participants who fail attention checks. In addition, we included our own internal data checks in keeping with Faunalytics' Data Quality Assurance Plan.

Power analyses indicated that a sample size of 497 per animal would allow for the detection of a small-to-medium effect size (rho $=.16$ ) with a power of .95 in a point-biserial correlation (critical $t$ =1.96). We included approximately 50 additional participants to account for exclusions due to poor data quality or the failure of attention-check questions. We removed fewer participants due to data cleaning than expected, so we had a total of 533 participants in the fish condition and 540 in the chicken condition. For additional details on the measures, power analysis, analysis plan, and more, please see the pre-registration documents on the Open Science Framework.

\section{Correlational Analyses}

Spearman rank order correlations were used for analyses. This is because the outcome variables were dichotomous and beliefs were rated on a Likert scale. Spearman's rank order performs a Pearson correlation on the rank values of the variables in question. It's appropriate to use with categorical and ordinal data, is more robust to violations of normality, and has only the assumption of a monotonic relationship between the variables in question. Power calculations are essentially identical as well. Therefore, we felt that Spearman's rank order was a more robust and appropriate test of the relationship between the variables than the Pearson correlation approach we originally preregistered. Results using Pearson point-biserial correlations closely match those obtained using Spearman's rank order: Only six of the correlations across the entire study were discordant for the inference of statistical significance between the two approaches.

Spearman's rank order correlations can be interpreted the same way as standard Pearson correlations. The scores range from -1 to 1 , with scores further away from zero indicating a stronger relationship between the variables in question. It is also an indication of effect size. 


\section{faunalytics}

Petition Measure

Originally, whether participants clicked the link to the petition after agreeing to sign it was intended to be the outcome measure for petitions in this study. However, due to a programming error, half of the click data was not captured, so we used agreement to sign the petition as the outcome measure instead.

\section{Average Correlation By Group Of Beliefs}

The average correlation for each group of beliefs are shown in Table 3 for fish and Table 4 for chickens. These were also provided in text in the body of the report.

To get these numbers, we averaged the absolute value of each of the correlations for the items in a group for each of the outcome variables. Because the number of people in each correlation was approximately the same, this "average of averages" approach does not weight any correlation unduly.)

Table 3: Average Correlation Of Fish Beliefs By Category

\begin{tabular}{|l|c|c|}
\hline Belief Category & Correlation Average & SD \\
\hline Fish personality and diet pledge & 0.20 & 0.05 \\
\hline Fish personality and petition & 0.16 & 0.03 \\
\hline Fish emotions and diet pledge & 0.18 & 0.03 \\
\hline Fish emotions and petition & 0.13 & 0.02 \\
\hline Fish suffering and diet pledge & 0.16 & 0.07 \\
\hline Fish suffering and petition & 0.13 & 0.03 \\
\hline Fish as food and diet pledge & 0.06 & 0.03 \\
\hline Fish as food and petition & 0.05 & 0.04 \\
\hline Fish intelligence and diet pledge & 0.16 & 0.09 \\
\hline Fish intelligence and petition & 0.12 & 0.10 \\
\hline Fish social and diet pledge & 0.16 & 0.06 \\
\hline Fish social and petition & 0.10 & 0.11 \\
\hline Fish other and diet pledge & 0.12 & 0.07 \\
\hline Fish other and petition & 0.17 & 0.07 \\
\hline
\end{tabular}




\section{Faunalytics}

Table 4: Average Correlation Of Chicken Beliefs By Category

\begin{tabular}{|l|c|c|}
\hline Belief Category & Correlation Average & SD \\
\hline Chicken personality and diet pledge & 0.19 & 0.03 \\
\hline Chicken personality and petition & 0.14 & 0.03 \\
\hline Chicken emotions and diet pledge & 0.19 & 0.02 \\
\hline Chicken emotions and petition & 0.14 & 0.01 \\
\hline Chicken suffering and diet pledge & 0.14 & 0.05 \\
\hline Chicken suffering and petition & 0.17 & 0.04 \\
\hline Chicken as food and diet pledge & 0.11 & 0.08 \\
\hline Chicken as food and petition & 0.07 & 0.05 \\
\hline Chicken intelligence and diet pledge & 0.18 & 0.06 \\
\hline Chicken intelligence and petition & 0.12 & 0.07 \\
\hline Chicken social and diet pledge & 0.13 & 0.01 \\
\hline Chicken social and petition & 0.10 & 0.01 \\
\hline Chicken other and diet pledge & 0.17 & 0.13 \\
\hline Chicken other and petition & 0.10 & 0.06 \\
\hline
\end{tabular}

As noted in the Results section, beliefs around the personality and emotions of chickens were the categories most strongly associated with diet pledges, whereas beliefs around chicken suffering were most strongly associated with petition signatures.

For fish, the personality group of beliefs was most strongly associated with pledges, while the "other" group of beliefs was most strongly associated with petition signatures. That said, the "other" group of beliefs has only three items, and the effect seems to have been driven mainly by the "Fish are beautiful" belief. Fish intelligence and personality were the other main categories associated with petition signatures.

\section{Individual Beliefs}

The results allowing for a comparison of all individual beliefs are presented in Table 5 for fish and Table 6 for chickens, below. 


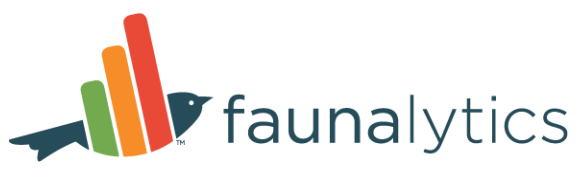

By default, the beliefs with the strongest average association with the two outcome variables are at the top of the list, but they can be resorted by any column if you prefer.

Table 5: Individual Fish Beliefs 


\section{-1) faunalytics}

\begin{tabular}{|c|c|c|c|c|c|}
\hline Belief & $\begin{array}{l}\text { Conceptual } \\
\text { Category }\end{array}$ & Mean & $\begin{array}{l}\text { Std. } \\
\text { Dev. }\end{array}$ & $\begin{array}{l}\text { Petition } \\
\text { Correlation }\end{array}$ & $\begin{array}{l}\text { Pledge } \\
\text { Correlation }\end{array}$ \\
\hline $\begin{array}{l}\text { Fish are more intelligent than people } \\
\text { give them credit for }\end{array}$ & Intelligence & 0.64 & 1.55 & $.26^{\star}$ & $.28^{\star}$ \\
\hline $\begin{array}{l}\text { Many of the farms that produce fish } \\
\text { have horrible living conditions }\end{array}$ & Suffering & 0.92 & 1.49 & $.19 \star$ & $.27^{\star}$ \\
\hline Fish play & Personality & 1.09 & 1.42 & $.18^{*}$ & $.26^{\star}$ \\
\hline Fish are loving & Personality & -0.34 & 1.55 & $.16^{\star}$ & $.26 *$ \\
\hline Fish are beautiful & Other & 1.58 & 1.34 & $.25^{\star}$ & $.16^{\star}$ \\
\hline Big fish farms are gross & Suffering & 0.55 & 1.64 & $.14^{\star}$ & $.25 \star$ \\
\hline Fish have no personality & Personality & -0.44 & 1.70 & $-.19 *$ & $-.19 *$ \\
\hline Fish can communicate with each other & Social & 1.45 & 1.35 & $.18^{*}$ & $.20 *$ \\
\hline Fish can feel negative emotions like fear & Emotions & 0.88 & 1.50 & $.14^{\star}$ & $.20^{\star}$ \\
\hline Fish can bond with humans & Personality & -0.11 & 1.68 & $.15^{\star}$ & $.18^{\star}$ \\
\hline Most farmed fish are raised inhumanely & Suffering & 0.48 & 1.50 & $.10^{\star}$ & $.24^{\star}$ \\
\hline $\begin{array}{l}\text { Individual fish don't have unique } \\
\text { characteristics }\end{array}$ & Personality & -0.93 & 1.63 & $-.16^{\star}$ & $-.15^{\star}$ \\
\hline $\begin{array}{l}\text { Fish can feel positive emotions like } \\
\text { pleasure }\end{array}$ & Emotions & 0.39 & 1.53 & $.11^{\star}$ & $.19^{\star}$ \\
\hline Fish need room to explore and exercise & Suffering & 1.70 & 1.24 & $.13^{*}$ & $.16^{*}$ \\
\hline Fish can feel stress & Emotions & 1.44 & 1.45 & $.14^{*}$ & $.15^{\star}$ \\
\hline $\begin{array}{l}\text { Fish are contaminated with plastics, } \\
\text { heavy metals, and chemicals }\end{array}$ & Other & 0.95 & 1.49 & $.11^{\star}$ & $.17^{\star}$ \\
\hline Fish are curious & Personality & 1.15 & 1.35 & $.12^{*}$ & $.16^{\star}$ \\
\hline Fish have a lower IQ than most animals & Intelligence & 0.59 & 1.51 & $-.10^{\star}$ & $-.17^{\star}$ \\
\hline $\begin{array}{l}\text { Fish don't care about being over- } \\
\text { crowded }\end{array}$ & Suffering & -1.41 & 1.56 & $-.14^{\star}$ & $-.12^{\star}$ \\
\hline $\begin{array}{l}\text { Fish don't mind being in a barren } \\
\text { environment }\end{array}$ & Suffering & -1.22 & 1.55 & $-.12^{*}$ & $-.13^{*}$ \\
\hline Fish can feel pain & Suffering & 1.71 & 1.28 & $.09 *$ & $.14^{\star}$ \\
\hline Water quality isn't that important to fish & Suffering & -2.25 & 1.18 & $-.14^{*}$ & -.08 \\
\hline $\begin{array}{l}\text { Fish never find it stressful to be picked } \\
\text { up or handled }\end{array}$ & Suffering & -1.79 & 1.47 & $-.11 *$ & $-.11 *$ \\
\hline Fish are gross & Other & -1.57 & 1.55 & $-.14^{\star}$ & -.05 \\
\hline $\begin{array}{l}\text { If fish products are labelled } \\
\text { "sustainable," they come from fish with } \\
\text { good welfare }\end{array}$ & As food & 0.05 & 1.45 & .063 & $.11^{\star}$ \\
\hline Fish can learn & Intelligence & 1.08 & 1.48 & .067 & $.10^{*}$ \\
\hline Fish don't care for their young & Social & -0.86 & 1.55 & -.024 & $-.12^{\star}$ \\
\hline Fish mostly act out of instinct & Intelligence & 1.39 & 1.25 & -.046 & -.08 \\
\hline $\begin{array}{l}\text { Eating fish doesn't contribute as much } \\
\text { to climate change as eating other } \\
\text { animals }\end{array}$ & As food & 0.18 & 1.45 & .010 & -.09 \\
\hline $\begin{array}{l}\text { Most fish people eat are caught wild in } \\
\text { the ocean }\end{array}$ & As food & -0.65 & 1.63 & .010 & .06 \\
\hline Fish are the healthiest animal to eat & As food & 0.47 & 1.29 & $11 *$ & -.04 \\
\hline
\end{tabular}


-1lv faunalytics

Table 6: Individual Chicken Beliefs 


\section{-1) faunalytics}

\begin{tabular}{|c|c|c|c|c|c|}
\hline Belief & $\begin{array}{l}\text { Conceptual } \\
\text { Category }\end{array}$ & Mean & $\begin{array}{l}\text { Std. } \\
\text { Dev. }\end{array}$ & $\begin{array}{l}\text { Petition } \\
\text { Correlation }\end{array}$ & $\begin{array}{l}\text { Pledge } \\
\text { Correlation }\end{array}$ \\
\hline $\begin{array}{l}\text { Chickens need room to explore and } \\
\text { exercise }\end{array}$ & Suffering & 1.88 & 1.26 & $.23^{\star}$ & $.24^{\star}$ \\
\hline Chickens are beautiful & Other & 0.49 & 1.61 & $.13^{*}$ & .31 \\
\hline $\begin{array}{l}\text { Chickens are more intelligent than } \\
\text { people give them credit for }\end{array}$ & Intelligence & 0.88 & 1.57 & $.20^{*}$ & $.22^{\star}$ \\
\hline $\begin{array}{l}\text { Many of the farms that produce } \\
\text { chickens have horrible living conditions }\end{array}$ & Suffering & 1.63 & 1.35 & $.22 *$ & $.16 *$ \\
\hline $\begin{array}{l}\text { Individual chickens don't have unique } \\
\text { characteristics }\end{array}$ & Personality & -1.34 & 1.39 & $-.18^{\star}$ & $-.19 \star$ \\
\hline Chickens are loving & Personality & 0.35 & 1.47 & $.13^{\star}$ & $.23^{*}$ \\
\hline Chickens play & Personality & 1.19 & 1.37 & $.16^{\star}$ & $.20^{\star}$ \\
\hline $\begin{array}{l}\text { Eating chickens doesn't contribute as } \\
\text { much to climate change as eating other } \\
\text { animals }\end{array}$ & As food & 0.06 & 1.48 & $-.13^{*}$ & $-.23^{\star}$ \\
\hline Chickens can feel stress & Emotions & 1.80 & 1.26 & $.15^{\star}$ & $.19 *$ \\
\hline $\begin{array}{l}\text { Chickens can feel positive emotions } \\
\text { like pleasure }\end{array}$ & Emotions & 1.27 & 1.37 & $.13^{*}$ & $.21 *$ \\
\hline Chickens have no personality & Personality & -1.21 & 1.45 & $-.12^{*}$ & $-.20 *$ \\
\hline $\begin{array}{l}\text { Chickens don't care about being over- } \\
\text { crowded }\end{array}$ & Suffering & -1.57 & 1.47 & $-.16 *$ & $-.16^{\star}$ \\
\hline Chickens can learn & Intelligence & 1.41 & 1.27 & $.13^{\star}$ & $.18^{\star}$ \\
\hline $\begin{array}{l}\text { Chickens can feel negative emotions } \\
\text { like fear }\end{array}$ & Emotions & 1.69 & 1.26 & $.14^{*}$ & $.17^{\star}$ \\
\hline $\begin{array}{l}\text { Chickens have a lower IQ than most } \\
\text { animals }\end{array}$ & Intelligence & 0.01 & 1.59 & $-.10^{\star}$ & $-.21 \star$ \\
\hline Chickens can feel pain & Suffering & 2.32 & 0.91 & $.17 *$ & $.13 *$ \\
\hline Most chickens are raised inhumanely & Suffering & 1.15 & 1.57 & $.13^{\star}$ & $.16^{\star}$ \\
\hline Chickens are gross & Suffering & -1.59 & 1.46 & $-.13^{\star}$ & $-.16^{\star}$ \\
\hline Chickens are curious & Personality & 1.39 & 1.33 & $.12^{\star}$ & $.17^{\star}$ \\
\hline Big chicken farms are gross & Other & 1.25 & 1.63 & $.17 *$ & $.12^{*}$ \\
\hline Chickens can bond with humans & Personality & 1.11 & 1.44 & $.12^{\star}$ & $.152^{\star}$ \\
\hline $\begin{array}{l}\text { Chickens are the most ethical animal to } \\
\text { eat }\end{array}$ & As food & -0.57 & 1.43 & $-.11^{\star}$ & $-.15^{\star}$ \\
\hline $\begin{array}{l}\text { Chickens don't mind being in a barren } \\
\text { environment }\end{array}$ & Suffering & -1.46 & 1.40 & $-.15^{\star}$ & $-.11^{\star}$ \\
\hline $\begin{array}{l}\text { Chickens never find it stressful to be } \\
\text { picked up or handled }\end{array}$ & Suffering & -1.73 & 1.29 & $-.15^{\star}$ & $-.12^{\star}$ \\
\hline $\begin{array}{l}\text { Chickens can communicate with each } \\
\text { other }\end{array}$ & Social & 1.66 & 1.16 & $.09 *$ & $.14^{\star}$ \\
\hline Chickens don't care for their young & Social & -1.72 & 1.27 & $-.11^{\star}$ & $-.12^{\star}$ \\
\hline $\begin{array}{l}\text { Air and water quality aren't that } \\
\text { important to chickens }\end{array}$ & Suffering & -1.97 & 1.34 & $-.12^{\star}$ & $-.09 *$ \\
\hline Chicken is a good source of protein & As food & 2.13 & 1.02 & -.03 & $-.12^{\star}$ \\
\hline
\end{tabular}

